\title{
Enhanced Nitrogen Loss from Rivers through \\ Coupled Nitrification-denitrification Caused by Suspended Sediment
}

\author{
Xinghui Xia ${ }^{a}$, , Ting Liu ${ }^{a}$, Zhifeng Yang ${ }^{a,}$, Greg Michalski ${ }^{\text {b, }}$, Shaoda Liu ${ }^{c}$, \\ Zhimei Jia ${ }^{\text {, }}$ Sibo Zhang ${ }^{\mathrm{a}}$
}

${ }^{a}$ School of Environment, Beijing Normal University / State Key Joint Laboratory of Environmental Simulation and Pollution Control, Beijing, 100875, China;

${ }^{\mathrm{b}}$ Department of Earth, Atmospheric and Planetary Sciences, Purdue University, West Lafayette, Indiana 47907, United States;

${ }^{\mathrm{c}}$ Department of Geography, National University of Singapore, 1 Arts Link, Kent Ridge, 117570, Singapore

*To whom correspondence should be addressed. E-mail:xiaxh@bnu.edu.cn (Xia, X.), zfyang@bnu.edu.cn (Yang, Z.), gmichals@purdue.edu (Michalski, G.). 


\section{Abstract}

Present-day estimations of global nitrogen loss (N-loss) are underestimated. Commonly, N-loss from rivers is thought to be caused by denitrification only in bed-sediments. However, coupled nitrification-denitrification occurring in overlying water with suspended sediments (SPS) where oxic and anoxic/low oxygen zones may coexist is ignored for N-loss in rivers. Here the Yellow and Yangtze Rivers were taken as examples to investigate the effect of SPS, which exists in many rivers of the world, on $\mathrm{N}$ loss through coupled nitrification-denitrification with nitrogen stable $\left({ }^{15} \mathrm{~N}\right)$ isotopic tracer simulation experiments and $i n$-situ investigation. The results showed even when SPS was surrounded by oxic waters, there were redox conditions that transitioned from an oxic surface layer to anoxic layer near the particle center, enabling coupled nitrification-denitrification to occur around SPS. The production rate of ${ }^{15} \mathrm{~N}_{2}$ from ${ }^{15} \mathrm{NH}_{4}{ }^{+}-\mathrm{N}\left(R_{15 \mathrm{~N} 2 \text {-production }}\right)$ increased with increasing SPS concentration $([S P S])$ as a power function $\left(R_{15 \mathrm{~N} 2 \text {-production }}=a \cdot[S P S]^{b}\right)$ for both the SPS-water and bed sediment-SPS-water systems. The power-functional increase of nitrifying and denitrifying bacteria population with [SPS] accounted for the enhanced coupled nitrification-denitrification rate in overlying water. SPS also accelerated denitrification in bed-sediment due to increased $\mathrm{NO}_{3}{ }^{-}$ concentration caused by SPS-mediated nitrification. For these two rivers, $1 \mathrm{~g} \mathrm{~L}^{-1}$ SPS will lead to $\mathrm{N}$-loss enhancement by approximately $25-120 \%$, and the enhancement increased with organic carbon content of SPS. Thus, we conclude that SPS in overlying water is a hot spot for nitrogen loss in river systems and current estimates of in-stream N-loss are underestimated without consideration of SPS; this may partially compensate for the current imbalance of global nitrogen inputs and sinks.

Keywords: coupled nitrification-denitrification; suspended sediment; nitrogen loss; rivers; nitrogen budget 
Nitrogen $(\mathrm{N})$, a major element required by all organisms, is widely applied in industry, agriculture, and domestic activities, but excess $\mathrm{N}$ can cause eutrophication and hypoxia in water bodies, destruction of habitats for resident organisms, and reduction of species diversity (Lenihan and Peterson, 1998; Mallin et al., 2006; Liu et al., 2013a; Roberts et al., 2014). Therefore, understanding the processes controlling $\mathrm{N}$ budget, such as the $\mathrm{N}$ fixation, assimilation, nitrification, and denitrification is vital. Yet, despite decades of research, the global $\mathrm{N}$ budget remains out of balance, with inputs exceeding losses (Galloway, 1998; Gruber and Galloway, 2008; Schlesinger, 2009). This imbalance indicates that some unknown processes might contribute to $\mathrm{N}$ losses, thus resulting in major uncertainties in model simulations and limiting the accuracy of forecasts of future river $\mathrm{N}$ export caused by climate change, urbanization, and human population growth.

Rivers are subject to high loads of nitrogen and can convert approximately $40 \%$ of terrestrial nitrogen $(\mathrm{N})$ runoff ( $\sim 47 \mathrm{Tg}$ per year) to biologically unavailable dinitrogen gas (Galloway et al., 2004). Nitrogen loss from rivers plays an important role for $\mathrm{N}$ delivery to coastal ecosystems (Donner and Kucharik, 2008), which often controls eutrophication and the development of pelagic “dead zones” (Turner and Rabalais, 1994; Rabalais, 2002; Diaz and Rosenberg, 2008). Studies of N loss from river systems have mainly focused on bed-sediment denitrification which is currently considered as the main in-stream $\mathrm{N}$ loss process (Boyer et al., 2006; Johannsen et al., 2008; Li et al., 2010; Liu et al., 2013b). Nitrification, the aerobic oxidation of $\mathrm{NH}_{4}{ }^{+}$to $\mathrm{NO}_{3}{ }^{-}$via $\mathrm{NO}_{2}{ }^{-}$performed primarily by ammonia-oxidizing bacteria and archaea, is an important nitrate supply that is subsequently transported to anaerobic zones in bed-sediments and reduced by denitrification in river systems (Seitzinger, 1988; Pina-Ochoa and Álvarez-Cobelas et al., 2006; Mulholland et al., 2008; Liu et al., 2013b). This suggests that nitrification and denitrification in rivers might be tightly coupled, however the timescale of nitrate diffusion at the water-sediment interface is thought to limit the role of bed-sediment denitrification in river systems (Venterink et al., 2003; O'Connor and Hondzo, 2007).

Although several studies suggested that coupled nitrification-denitrification (CND) might occur in water column of some estuaries with high turbidity (Abril et al., 2000; Sebilo et al., 2006), N loss 
in river systems by CND occurring in water column containing suspended sediments (SPS) where possible anoxic/low oxygen microsites may exist has been largely ignored. SPS exists in many rivers around the world (Mulder and Syvitski, 1995; Sivakumar, 2002; Billi and Ali, 2010; Water Conservancy Committee of the Yellow River, 2013), and it has been shown that nitrification rates increase with SPS concentration (Xia et al., 2004; Xia et al., 2009). Additionally, it has been proven that denitrification rate increases linearly with SPS concentration in oxic waters according to the results of incubation experiment with added ${ }^{15} \mathrm{NO}_{3}^{-}-\mathrm{N}$ (Liu et al., 2013b), and Reisinger et al (2016) found denitrification occurring in the water column of certain rivers. The anoxic/low oxygen microsites were assumed to exist in suspended particles surrounded by oxidized waters according to the theories of transport limitations and multispecies biofilms (Lamontag.Ra et al., 1973; Bianchi et al., 1992; Michotey and Bonin, 1997; Falkowski et al., 2008). Building on these recent findings, we hypothesized that a gradient of oxic and anoxic/low oxygen conditions exists within SPS particles with oxic conditions at the surface layer and anoxic/low oxygen conditions near the center of particle. Then CND could occur in oxic waters in the presence of SPS, with nitrification occurring at the surface layer and denitrification occurring in the inner layer of SPS. In addition to providing oxygen-limited microsites for denitrification, SPS will also accelerate river denitrification rates by generating more $\mathrm{NO}_{3}{ }^{-}$from SPS, which increases $\mathrm{NO}_{3}{ }^{-}$concentration gradients between overlying water and bed-sediment and thus enhances diffusion rates, promoting bed-sediment denitrification in river systems.

Therefore, we hypothesized that there will be enhanced N-loss through CND and other nitrogen transformation processes in river systems where there are significant amounts of SPS. The influences of SPS concentration on N loss in the Yellow River and the Yangtze River were investigated using isotopic and chemical techniques; the SPS concentration of these two rivers ranged from 0.01 to 54.8 $\mathrm{g} \mathrm{L}^{-1}$ and from 0.01 to $10.5 \mathrm{~g} \mathrm{~L}^{-1}$, respectively (Changjiang Water Resource Committee, 2014; Xia et al., 2016). In detail, the present study aimed to: 1) examine whether CND could occur at SPS particles, and explore the relevant mechanisms; 2) investigate and model the relationship between CND rate and SPS concentration; 3) estimate the impacts of enhanced CND by SPS on N-loss from river systems. 


\subsection{Sample collection}

Sediment and water samples used in incubation experiments were collected from five sites

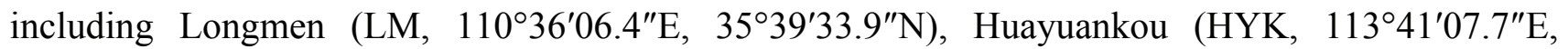
$\left.34^{\circ} 54^{\prime} 16.8^{\prime \prime} \mathrm{N}\right)$, and Aishan (AS, 116 16'39.7"E, 36 $\left.16^{\circ} 44.4^{\prime \prime} \mathrm{N}\right)$ Stations in the Yellow River and 37-Dock (37-Dock, $\left.114^{\circ} 20^{\prime} 09.5^{\prime \prime} \mathrm{E}, 30^{\circ} 36^{\prime} 30.5^{\prime \prime} \mathrm{N}\right)$ and Wanzhou (WZ, 108²2'56.30"E, $30^{\circ} 48^{\prime} 39.85^{\prime \prime N}$ ) Stations in the Yangtze River (Fig.1). To avoid being contaminated by surface pollutants, water samples at $0.2 \mathrm{~m}$ below the water surface were collected with a TC-Y sampler (TECH Instrument in Shenyang, China), and analyzed for properties including the content of organic carbon and nitrogen species (see below). The top 10-cm bed-sediment samples, which are more easily re-suspended during flow fluctuation, were collected with a sediment grab sampler. In addition, SPS and water samples were collected from 17 sites of the Yellow River to study the effect of SPS concentration on in-situ nitrifying and denitrifying bacteria abundances (Fig.1). Then all the above samples were kept under $4^{\circ} \mathrm{C}$ in a cooler and shipped to laboratory for further analysis. Incubation experiments began within $48 \mathrm{~h}$ after sampling. The sediment characteristics at the five sampling sites of the Yellow River and the Yangtze River are shown in Table 1.

\subsection{Incubation of SPS-water systems with various SPS concentrations}

Taking the samples collected from site AS as an example to examine whether CND could occur on SPS particles, a set of chambers containing SPS and water but no bed-sediment were designed. The experimental design was similar to our previous study (Liu et al., 2013b). A series of chambers containing 800-ml artificial overlying water with $5 \mathrm{mgL}^{-1}{ }^{15} \mathrm{NH}_{4}{ }^{+}-\mathrm{N}$ as ${ }^{15} \mathrm{NH}_{4}{ }^{+} \mathrm{Cl}\left(99.0\right.$ atm $\%{ }^{15} \mathrm{~N}$, Shanghai Research Institute of Chemical Industry, China) were designed to obtain a 20-cm-deep water column. The artificial overlying water contained indigenous bacteria in the Yellow River and its preparation is shown in Supplementary Section S1. Triplicate experiments were conducted for each incubation set. A certain amount $(0,0.8,2,6.4,12$ and $16 \mathrm{~g})$ of homogenized bed-sediment was respectively added into each chamber, which were then incubated at $25^{\circ} \mathrm{C}$. All the added sediment was suspended by setting agitation rates at 50,150, 200, 400, 550, and $700 \mathrm{r} \mathrm{min}^{-1}$, obtaining SPS 
concentrations of $0,1,2.5,8,15$, and $20 \mathrm{~g} \mathrm{~L}^{-1}$, respectively. The chemical conditions of water in each chamber were the same (Supplementary Table S1), and they are similar to that of river water. At pre-determined intervals (every three days), gas from headspace produced during each incubation period was sampled using a gas-tight syringe for the measurement of $\delta^{15} \mathrm{~N}-\mathrm{N}_{2}$, and then the concentration excess ${ }^{15} \mathrm{~N}-\mathrm{N}_{2}$ was calculated. The remaining ${ }^{15} \mathrm{~N}_{2}$ produced during previous incubation period was purged by aerating the water phase for $30 \mathrm{~min}$, and the aeration also helped keep oxygen level at saturation. The dissolved oxygen concentration was determined after each sampling and it was approximately $8.2 \mathrm{mg} \mathrm{L}^{-1}$ during experiment. At the end of experiment, sediment and water were separated by letting the sediment settle out, and the density of denitrifying bacteria in the SPS and water samples was measured using the most-probable-number-PCR (MPN-PCR) method (section 2.6 and Supplementary Section S3). The control sets were performed using sterilized sediment and water samples, and mercuric chloride was added to the control sets with a final concentration of $0.5 \%$ to inhibit the microbial activities. The production of ${ }^{15} \mathrm{~N}_{2}$ caused by microbial activities was calculated by subtracting ${ }^{15} \mathrm{~N}_{2}$ produced in the control systems from that in each incubation set.

In addition, the mechanisms accounting for the occurrence of CND on SPS particles were analyzed by examining the $\mathrm{O}_{2}$ flux and profile around the SPS particle. To do this, one more set of chambers containing $800 \mathrm{ml}$ solution with $5 \mathrm{mg} \mathrm{L}^{-1} \mathrm{NH}_{4}{ }^{+}-\mathrm{N}$ and $20 \mathrm{~g} \mathrm{~L}^{-1}$ SPS of different sizes $(<20$ $\mu \mathrm{m}, 20-50 \mu \mathrm{m}, 50-100 \mu \mathrm{m}$, and $>100 \mu \mathrm{m}$ ), which were separated by wet screening and sedimentation methods using samples collected from the site AS, were incubated at $25^{\circ} \mathrm{C}$. The detection of $\mathrm{O}_{2}$ flux and profile around SPS particles was performed using Non-invasive Micro-test Technology and microelectrode technology (Jaffe and Nuccitelli, 1974; Revsbech, 1989; Smith, 1995), respectively. The details for the determination are described in Supplementary Section S2.

\subsection{Incubation of bed sediment-SPS-water system with various SPS concentrations}

A 10-cm-deep sediment column was constructed by adding a certain amount of homogenized bed-sediment into the gastight polymethyl methacrylate (PMMA) incubation chambers, as described by Liu et al.(2013b). Then the sediment was covered by $800 \mathrm{ml}$ artificial overlying water with $5 \mathrm{mg}$ $\mathrm{L}^{-1}{ }^{15} \mathrm{NH}_{4}{ }^{+}-\mathrm{N}$. Triplicate experiments were conducted for each incubation set. The SPS concentrations 
were set at $20,15,8,2.5,1$, and $0 \mathrm{~g} \mathrm{~L}^{-1}$ by adjusting the agitation rates at $700,550,400,200,150$, and $0 \mathrm{r} \mathrm{min}^{-1}$ respectively, simulating the real rivers containing different concentrations of SPS. The variation of measured SPS concentration in each chamber was less than $5 \%$ of the pre-set one. The particle size of SPS in the systems containing different concentrations of SPS was similar to that of SPS in real rivers (Supplementary Table S2). All the chambers were incubated at $25{ }^{\circ} \mathrm{C}$. At pre-determined intervals (every one to three days), water samples were sucked out of the chamber using a columnar sampler as described in Liu et al.(2013b); the other procedures including gas sampling and aeration were the same as that mentioned at Section 2.2. At the end of incubation, the water phase containing SPS was decanted; SPS and water were separated by standing for $12 \mathrm{~h}$. The denitrifying and nitrifying bacteria densities in the water phase, bed-sediment, and SPS samples were measured using MPN-PCR method. The CND rate was calculated according to the production of ${ }^{15} \mathrm{~N}_{2}$, while nitrification rate was calculated according to the variation of $\mathrm{NH}_{4}{ }^{+}-\mathrm{N}$ concentration in the systems. To distinguish the contribution of SPS itself and agitation to the increased N loss through CND caused by the presence of SPS, another experiment set was carried out for systems containing bed-sediment and water (BS-WS) without agitation using samples collected from site AS. The control sets were conducted as the same as that mentioned at Section 2.2.

\subsection{Incubation of bed sediment-SPS-water system with various nitrate concentration}

To investigate the influencing mechanisms of SPS concentration on CND, the effect of initial $\mathrm{NO}_{3}{ }^{-}$concentration $\left(\left[\mathrm{NO}_{3}{ }^{-}\right]\right)$on denitrification was investigated by using samples collected from the site HYK. The 10-cm-deep sediment columns were constructed using the same method as Section 2.3 , then $800 \mathrm{ml}$ artificial overlying water containing $10,6,4.5,3$ and $1 \mathrm{mg} \mathrm{L}^{-1} \mathrm{NO}_{3}{ }^{-}-\mathrm{N}$ as $\mathrm{KNO}_{3}$ were respectively added into each chamber. These concentrations are within the range of $\mathrm{NO}_{3}{ }^{-}$ concentration detected in the Yellow River (Xia et al., 2002). Triplicate experiments were conducted for each incubation set. The SPS concentration in each column was set at $8 \mathrm{~g} \mathrm{~L}^{-1}$ by adjusting agitation rate, which occurred in the temperate seasons (October-November and March-June) in the Yellow River. Then all the chambers were incubated at $25{ }^{\circ} \mathrm{C}$. At pre-determined intervals (every two to four days), bed-sediment, SPS, and water samples were collected by using columnar samplers, and the samples were then put into tubes to separate sediment (including SPS and bed-sediment) and 
water phases by centrifuge; sediment and water samples were subsequently analyzed for the concentrations of $\mathrm{N}$ species. The denitrification rate was calculated according to the variation of $\left[\mathrm{NO}_{3}{ }^{-}\right]$in the systems including SPS, bed-sediment, and water phases. The other experimental procedures were the same as that in Section 2.3. All the above mentioned experimental conditions are summarized in Table 2.

\subsection{Chemical analysis}

Water sample was filtrated through $0.45 \mu \mathrm{m}$ filters (Millipore corp. USA), and analyzed for $\mathrm{NO}_{3}{ }^{-}-\mathrm{N}, \mathrm{NO}_{2}{ }^{-}-\mathrm{N}$, and $\mathrm{NH}_{4}{ }^{+}-\mathrm{N}$ concentrations immediately. The $\mathrm{NO}_{3}{ }^{-}-\mathrm{N}, \mathrm{NO}_{2}{ }^{-}-\mathrm{N}$, and $\mathrm{NH}_{4}{ }^{+}-\mathrm{N}$ contents in sediment were analyzed after extraction with $\mathrm{KCl}$ solution (2M). Dissolved nitrogen $\left(\mathrm{NO}_{3}{ }^{-}-\mathrm{N}, \mathrm{NO}_{2}{ }^{-}-\mathrm{N}\right.$, and $\left.\mathrm{NH}_{4}{ }^{+}-\mathrm{N}\right)$ concentrations were detected using an Autoanalyser-3 (Bran \& Luebbe, France). Organic nitrogen contents in the sediment and water were measured after Kjeldahl digestion. Analytical reagents were used throughout the chemical analysis. The standard deviations for standards and replicate analysis were less than $4.4 \%, 2.8 \%, 5.4 \%, 5.0 \%$ for $\mathrm{NH}_{4}^{+}-\mathrm{N}, \mathrm{NO}_{2}^{-}-\mathrm{N}$, $\mathrm{NO}_{3}{ }^{-} \mathrm{N}$ and organic nitrogen, respectively. The ${ }^{15} \mathrm{~N}_{2}$ in gas samples was detected through using an isotopic ratio mass spectrometer (Thermo Delta V Advantage), in line with an automated gas PreCon unit. Nitrogen isotope ratios (including 29/28 and 30/28) of the samples were expressed as standard $\delta$ notation (\%o) relative to atmospheric $\mathrm{N}_{2}$. The standard deviation for standards and replicate analysis of the $\delta^{15} \mathrm{~N}$ measurement was better than $0.2 \%$.

\subsection{Biological and statistical analysis}

To investigate the abundances of denitrifying and nitrifying bacteria in SPS particles, 
bed-sediment, and overlying water samples, DNA from the water and/or sediment were extracted using an Ultra Clean Soil DNA Isolation Kit (Mo-bio Laboratories, Inc., Carlsbad, CA, USA). The extracted DNA were stored at $-20^{\circ} \mathrm{C}$ until analysis by most-probable-number (MPN)-PCR (Cochran, 1950; Rotthauwe et al., 1997; Liu et al., 2003). The detailed procedures on MPN-PCR are shown in Supplementary Section S3.

SPSS 18.0 for windows (SPSS Inc., Chicago IL., USA) was used for all statistical analyses in this research, including correlation analysis, nonlinear fitting, and variance analysis. The significance of correlation between each two variables was tested by calculating the Pearson correlation coefficient, and the significant differences among groups were tested with Duncan's multiple range test.

\section{Results and Discussion}

\subsection{Effect of SPS concentration on CND in oxic SPS-water system}

\subsubsection{Dependence of CND rate on SPS concentration}

The presence of CND in SPS-water system (SPS-WS) was assessed by measuring the ${ }^{15} \mathrm{~N}_{2}-\mathrm{N}$ production from a ${ }^{15} \mathrm{NH}_{4}{ }^{+} \mathrm{N}$ addition, which can only occur by ${ }^{15} \mathrm{NO}_{3}^{-}$production through nitrification of ${ }^{15} \mathrm{NH}_{4}{ }^{+}-\mathrm{N}$ followed by its reduction to ${ }^{15} \mathrm{~N}_{2}$ during denitrification or anammox. According to our research (submitted to Biogeochemistry), the ${ }^{15} \mathrm{~N}_{2}$ production from anammox was very low in SPS-water system of the Yellow River, thus the ${ }^{15} \mathrm{~N}_{2}$ production was primarily from CND in the present research. The average CND rate, expressed as ${ }^{15} \mathrm{~N}_{2}-\mathrm{N}$ production, followed a power function with SPS concentration, and jumped from 25 to $264 \mu \mathrm{g}-\mathrm{N} \mathrm{m} \mathrm{m}^{-2} \mathrm{~d}^{-1}$ when the concentration of SPS was elevated from 0 to $20 \mathrm{~g} \mathrm{~L}^{-1}$ (Fig. 2a). Even a low concentration of SPS (1 g $\mathrm{L}^{-1}$ ) resulted in an 8 -fold increase in the ${ }^{15} \mathrm{~N}_{2}-\mathrm{N}$ production relative to water without SPS. In addition, both nitrifying and denitrifying bacteria populations increased with increasing SPS concentration (Fig. 2b) as power functions respectively $(\mathrm{p}<0.05)$, and they were positively correlated with the average CND rate (Fig. S1). This data suggest SPS was providing conditions for CND to occur.

\subsubsection{Conditions provided by SPS for CND}

The activity of SPS particle was investigated by determining the $\mathrm{O}_{2}$ flux and dissolved $\mathrm{O}_{2}$ (DO) 
217 around the particle. The observed high $\mathrm{O}_{2}$ influx around SPS particles and decrease in DO 218 concentrations (Fig. 3, Fig. S2 and S3) suggest that oxygen was being consumed near SPS particle 219 surfaces by nitrification and/or microbial respiration. The DO concentration in the bulk solution was approximately $8.2 \mathrm{mg} \mathrm{L}^{-1}\left(100 \%\right.$ air saturated), but it decreased to less than $53 \% \mathrm{O}_{2}$ saturation near the surface for particles with size $<100 \mu \mathrm{m}$, and the decrease was the sharpest near the surface of particles. Similarly, maximum increases in the $\mathrm{O}_{2}$ influx $\left(-2.073\right.$ to $\left.-0.612 \mathrm{pmol} \mathrm{cm}^{-2} \mathrm{~s}^{-1}\right)$ occurred near particle surface regardless of particle size. Particles with diameters smaller than $20 \mu \mathrm{m}$ had the largest overall increase in $\mathrm{O}_{2}$ influx (Fig. S3); this is likely caused by the higher organic carbon content (\%) and larger specific surface area of smaller particles compared with particles with larger sizes (Table S3). Despite differences in $\mathrm{O}_{2}$ influxes among particles of different sizes, the above results indicate a gradient of oxic and low oxygen conditions exists within SPS particles with oxic conditions at the surface layer and low oxygen conditions near the center of particle. It infers that SPS particles can act as activated redox sites for microbial nitrification and denitrification because some bacteria can conduct denitrification under limited/low oxygen conditions. According to our previous research (Liu et al., 2013b), most of the denitrifying bacteria in the Yellow River are facultative bacteria and can conduct denitrification under limited/low oxygen conditions (oxygen level $<53 \%$ and $<70 \%$ of the saturated $\mathrm{O}_{2}$ concentration, respectively). Therefore, the presence of SPS in the Yellow River can provide microsite redox conditions needed for CND. In addition, because the SPS used in our incubation experiment had lower organic carbon contents than other rivers (Table S4), the SPS in other rivers might provide low/limited oxygen even anoxic micro-environments for denitrification.

Therefore, the mechanisms about the influence of SPS on CND in oxic waters can be analyzed as follows. The nitrifying bacteria distribute on the outer layer of particles and perform nitrification under high oxygen conditions, and the denitrifying bacteria reduced nitrate to $\mathrm{N}_{2}$ at the deep layer of particles under low oxygen conditions. That is to say, firstly, the oxic conditions and $\mathrm{NH}_{4}{ }^{+}-\mathrm{N}$ adsorbed on the surface layer of suspended particles favor nitrification, and the nitrification rate rises with SPS concentration as a power function due to the fact that the percentage of $\mathrm{NH}_{4}{ }^{+}-\mathrm{N}$ sorbed on SPS increases with SPS concentration following a power function (Xia et al., 2009). Secondly, not 
only respiration by heterotrophic bacteria but nitrification at SPS particles lead to the presence of microsites with limited/low oxygen around/inside SPS particles, providing conditions for denitrification. The existence of both oxygen-limited microsites and denitrifying bacteria within the SPS particles promotes denitrification. These relationships between nitrification and denitrification at SPS particles lead to the occurrence of CND at SPS particles, as well as the accelerated CND rate with SPS concentration.

The positive correlation of nitrification with SPS concentration has been observed for river systems (Xia et al., 2009; Hsiao et al., 2014), and such a correlation has been reported in the relatively turbid region of estuaries with higher nitrification activities (Helder and De Vries, 1983; Owens, 1986; Berounsky and Nixon, 1993). In addition, although denitrification is most commonly observed in anoxic sediments, this process has also been reported for oxic environments where anoxic micro environments are thought to be associated with suspended particle surfaces and/or biofilms (Rao et al., 2008; Liu et al., 2013b; Reisinger et al., 2016). Furthermore, for the high-turbidity river mouth, the amoA and nirS genes abundances of the particle-associated ( $>3 \mu \mathrm{m})$ were found to be significantly higher than the free-living communities $(0.2 \sim 3 \mu \mathrm{m})$ (Zhang et al., 2014). These research results suggest that the suspended particles and biofilms can promote both nitrification and denitrification in freshwater and seawater systems, which is probably due to the fact that the particles and biofilms can provide microsite redox conditions for both nitrification and denitrification.

\subsection{Influence of SPS concentration on CND in bed sediment-SPS-water system}

\subsubsection{Increased ${ }^{15} \mathrm{~N}_{2}$ production from ${ }^{15} \mathrm{NH}_{4}{ }^{+}$with SPS concentration}

The production of ${ }^{15} \mathrm{~N}_{2}$ produced by CND increased with incubation time and SPS concentration for the bed sediment-SPS-water system (BS-SPS-WS) using samples collected from five sites of the Yellow and Yangtze Rivers (Fig. 4 and Fig. S4). The average ${ }^{15} \mathrm{~N}_{2}$ production rate increased dramatically with SPS concentration at low SPS concentrations and the increase tapered off at higher SPS concentrations. For the HYK sample, the ${ }^{15} \mathrm{~N}_{2}$ production rate increased by $0.1 \mathrm{mg}-\mathrm{N} \mathrm{m}^{-2} \mathrm{~d}^{-1}$ when SPS concentration increased from 0 to $1 \mathrm{~g} \mathrm{~L}^{-1}$, but only increased by an additional $0.008 \mathrm{mg}-\mathrm{N}$ $\mathrm{m}^{-2} \mathrm{~d}^{-1}$ when SPS increased from 1 to $20 \mathrm{~g} \mathrm{~L}^{-1}$. 
The average ${ }^{15} \mathrm{~N}_{2}$ production rate $\left(R_{15 N 2 \text {-production }}, \mathrm{mg-N} \mathrm{m}^{-2} \mathrm{~d}^{-1}\right)$ during incubation in BS-SPS-WS

274 increased with SPS concentration ([SPS], $\mathrm{g} \mathrm{L}^{-1}$ ) as a power function for all of the five study sites (Fig. 275 5):

$$
R_{15 N 2-\text { production }}=\mathrm{a} \cdot[S P S]^{\mathrm{b}}
$$

This indicates the universality of the relationship between N-loss rate and SPS concentration. As shown in Fig. S5, the constant $a$, reflecting the nitrogen loss rate with $1 \mathrm{~g} \mathrm{~L}^{-1} \mathrm{SPS}$, was positively related to the TOC content of SPS and the percentage of particles smaller than $20 \mu \mathrm{m}(\mathrm{p}<0.05)$. The constant $b$, reflecting the dependence of N-loss on SPS concentration, was also positively related to the TOC content of SPS $(p<0.05)$. This was probably due to the fact that high TOC content favored the growth of heterotrophic denitrifying bacteria. Smaller particles might provide more favorable conditions for CND due to the sharper decrease of $\mathrm{O}_{2}$ concentration near the particles and provided more sites for bacteria to grow due to larger specific surface areas. According to our previous research, the denitrification rate was negatively related to particle size of SPS in oxic waters (Jia et al., 2016). The enhancement of the N-loss rate by the presence of SPS differed among samples collected from various sites, indicating local biogeochemical conditions can control N-loss. For example, the sediments at site WZ of the Yangtze River that had the highest fine particle $(<20 \mu \mathrm{m})$ percentage and TOC content among the five study sites also had the highest N-loss rate.

\subsubsection{Influence of SPS concentration on nitrogen transformation}

The presence of SPS accelerated the transformation of $\mathrm{NH}_{4}{ }^{+}-\mathrm{N}$ to $\mathrm{NO}_{3}{ }^{-} \mathrm{N}$ (Fig. 6 and Fig. 7).

292 For the HYK sample, $\mathrm{NH}_{4}{ }^{+}$concentration $\left(\left[\mathrm{NH}_{4}{ }^{+}\right]\right)$decreased nearly to zero by the $11^{\text {th }}$ day in systems when SPS concentrations were between 8 and $20 \mathrm{~g} \mathrm{~L}^{-1}$, while it remained over $1.5 \mathrm{mg} \mathrm{L}^{-1}$ in the system without SPS after 31 days of incubation. The average $\mathrm{NH}_{4}{ }^{+}-\mathrm{N}$ loss rate at the first nine days ascended with SPS concentration by a power function $(\mathrm{r}=0.921, \mathrm{p}<0.01$, Fig. 7). Correspondingly, the $\mathrm{NO}_{3}{ }^{-}$concentration $\left(\left[\mathrm{NO}_{3}{ }^{-}\right]\right.$) increased and the ${ }^{15} \mathrm{~N}_{2}$ evolved from each column along with the decrease in $\left[\mathrm{NH}_{4}^{+}\right]$(Fig. 6), supporting the hypothesis of coupled nitrification-denitrification. However, a certain amount of $\mathrm{NO}_{3}{ }^{-}-\mathrm{N}$ was accumulated in systems, which meant not all of the $\mathrm{NO}_{3}{ }^{-} \mathrm{N}$ produced from nitrification was denitrified immediately. 
In the incubation experiments of bed sediment-SPS-water system, ammonification, anammox, 301 dissimilatory nitrate reduction to ammonium (DNRA), and inorganic nitrogen uptake may occur simultaneously in addition to nitrification and denitrification processes. Overall, approximately $1.8 \%$, $3.6 \%, 6.4 \%, 12 \%$, and $20 \%$ of the added ${ }^{15} \mathrm{~N}$ in the form of $\mathrm{NH}_{4}{ }^{+}-\mathrm{N}$ has been transformed into $\mathrm{N}_{2}$ after incubation for $31 \mathrm{~d}$ for the bed sediment-SPS-water system containing $20 \mathrm{~g} \mathrm{~L}^{-1}$ SPS collected from HYK, LM, AS, 37 Dock, and WZ Stations, respectively. In detail, taking the HYK for example (Table S3), approximately $1.80 \%$ and $71.8 \%$ of the added ${ }^{15} \mathrm{~N}$ in the form of $\mathrm{NH}_{4}{ }^{+} \mathrm{N}$ has been transformed into $\mathrm{N}_{2}$ and $\mathrm{NO}_{3}{ }^{-}$for the incubations with $20 \mathrm{~g} \mathrm{~L}^{-1}$ SPS, respectively; approximately 5.09\% remained as $\mathrm{NH}_{4}^{+}$and $21.3 \%$ assimilated by organisms based on the mass balance of added $\mathrm{NH}_{4}{ }^{+}-\mathrm{N}$.

The variation of $\mathrm{NH}_{4}{ }^{+}$concentration was affected by ammonification, nitrification, anammox, DNRA, and its uptake by heterotrophic organisms. As shown in Fig. 6 for the HYK sample, $\mathrm{NH}_{4}{ }^{+}$ concentration increased during the first three days of the incubation systems with SPS concentration less than $2.5 \mathrm{~g} / \mathrm{L}$; this might be ascribed to the ammonification. After that, $\mathrm{NH}_{4}{ }^{+}$concentration decreased significantly, suggesting that nitrification, anammox, and uptake by heterotrophic organisms controlled the variation of $\mathrm{NH}_{4}{ }^{+}$. Although Lansdown et al. (2016) found that anammox can represent an important nitrogen loss pathway in permeable river sediments, some researchers reported that the contribution of anammox process, in the riverine sediments, to the N-loss was approximately 10\% (Dale et al., 2009; Wang et al., 2012; Zhu et al., 2015). The anammox process might be less significant than nitrification in the present research because the sediment was different from that studied by Lansdown et al. In addition, the fraction of $\mathrm{NH}_{4}^{+}$transformed to $\mathrm{NO}_{3}^{-}$ (55.6\%-89.5\%) was much higher than the assimilation (3.71\%-28.9\%) (Table S5). The variation of $\mathrm{NO}_{3}{ }^{-}$concentration would be affected by nitrification, DNRA, and denitrification. DNRA has been shown as significant in many organic rich sediments and for instance during oxic-anoxic oscillations (Abril et al., 2010). As less than $23 \%$ of the added $\mathrm{NH}_{4}{ }^{+}$remained as $\mathrm{NH}_{4}{ }^{+}$, the DNRA must be much less significant than nitrification in the present research. In addition, the TOC content of the sediment sample was low (Table 1), therefore, the DNRA might be not significant in the incubations of the present research. However, SPS might provide oxic-anoxic oscillations for DNRA in other rivers, and more research should be conducted in this regard. 
According to the above analysis, the variations of $\mathrm{NH}_{4}{ }^{+}$and $\mathrm{NO}_{3}{ }^{-}$in the incubation systems resulted from several processes. However, the transformation of added $\mathrm{NH}_{4}{ }^{+}$was mainly controlled by nitrification and denitrification. Therefore, the processes were simplified as nitrification and denitrifciation to study the nitrogen transformation kinetics of the present research. The following logistic model was used to analyze $\mathrm{NH}_{4}{ }^{+}-\mathrm{N}$ variation during nitrification:

$$
\left(-\frac{d S_{N H_{4}^{+}}}{d t}\right)_{\text {nitrification }}=\frac{\mu_{\text {max }- \text { nitrifier }} S_{N H_{4}^{+}}\left(S_{N H_{4}^{+} 0}+X_{0-\text { nitrifier }}-S_{N H_{4}^{+}}\right)}{k_{s-n i t r i f i e r}}
$$

the integral form of equation (2) is:

$$
S_{N H_{4}^{+}}=\frac{S_{N H_{4}^{+} 0}+X_{0-\text { nitrifier }}}{1+\left(X_{0 \text { nitrifier }} / S_{N H_{4}^{+} 0}\right) \cdot e^{k_{\text {nitrification }}\left(S_{N H_{4}^{+} 0}+X_{0-\text { nirifier }}\right) t}}
$$

where $S_{\mathrm{NH} 4+}$ represents the $\left[\mathrm{NH}_{4}^{+}\right]$at time $t\left(\mathrm{mg} \mathrm{L}^{-1}\right) ; S_{\mathrm{NH} 4+0}$ represents the $\left[\mathrm{NH}_{4}^{+}\right]$in the beginning $\left(\mathrm{mg} \mathrm{L}^{-1}\right) ; \mathrm{X}_{0 \text {-nitrifier }}$ represents the bacterial population quota in the beginning $\left(\mathrm{mg} \mathrm{L}^{-1}\right) ; k_{\text {nitrification }}$ represents the nitrification rate constant $\left(\mathrm{d}^{-1}\left(\mathrm{mgL}^{-1}\right)^{-1}\right), k_{\text {nitrification }}=\mu_{\text {max-nitrifier }} / K_{\text {s-nitrifier }} ; \mu_{\text {max-nitrifier }}$ represents the maximum specific growth rate of nitrifying bacteria $\left(\mathrm{d}^{-1}\right) ; K_{\mathrm{s}-\mathrm{nitrifier}}$ represents the half-saturation growth constant for nitrifying bacteria $\left(\mathrm{mg} \mathrm{L}^{-1}\right)$. The $\mathrm{NH}_{4}{ }^{+}-\mathrm{N}$ variation in systems containing various SPS concentrations fit well with the Logistic model shown in equation $(2)(\mathrm{p}<$ $0.01)$, and the nitrification rate constant $\left(k_{\text {nitrification }}\right)$ increased with SPS concentration conforming to a power function ( $<<0.01$, Fig. 7 and Table 3$)$.

The variation of nitrate during CND depends on relative nitrification and denitrification rates, and the latter was described by the Monod kinetics:

$$
\frac{d S_{N O_{3}^{-}}}{d t}=\frac{d\left(S_{N H_{4}^{+} 0}-S_{N H_{4}^{+}}\right)}{d t}-\left(\frac{\mu_{\text {max }- \text { denitrifier }} S_{N_{\overline{3}}^{-}}\left(S_{N O_{3} 0}+X_{0-d e n i t r i f i e r}-S_{N O_{3}^{-}}\right)}{\left(K_{s-d e n i r i f i e r}+S_{N O_{3}^{-}}\right)}\right)
$$

where $S_{\mathrm{NO} 3-}$ represents the $\left[\mathrm{NO}_{3}{ }^{-}\right]$at time $\mathrm{t}\left(\mathrm{mg} \mathrm{L} \mathrm{L}^{-1}\right) ; S_{\mathrm{NO} 3-0}$ represents the initial $\left[\mathrm{NO}_{3}{ }^{-}\right]\left(\mathrm{mg} \mathrm{L}^{-1}\right)$; $\mu_{\text {max-denitrifier }}$ represents the maximum specific growth rate of denitrifying bacteria $\left(\mathrm{d}^{-1}\right) ; X_{0 \text {-denitrifier }}$ represents the denitrifying bacterial population quota in the beginning $\left(\mathrm{mg} \mathrm{L}^{-1}\right) ; K_{\mathrm{s}-\text { denitrifier }}$ represents the half-saturation growth constant for denitrifying bacteria $\left(\mathrm{mg} \mathrm{L}^{-1}\right)$. As shown in Fig. 6, the kinetics 
of nitrate in system could be divided into two stages. At the first stage, $\left[\mathrm{NO}_{3}{ }^{-}\right]$increased with time; the denitrifying bacteria was much higher than $\left[\mathrm{NO}_{3}{ }^{-}\right]$at time zero $\left(X_{0 \text {-denitrifier }}>>S_{\mathrm{NO} 3-0}\right)$ and the

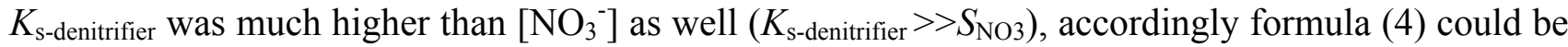
simplified as equation (4-1). At the second stage, $\left[\mathrm{NO}_{3}^{-}\right]$decreased with time while $\left[\mathrm{NH}_{4}^{+}\right]$kept

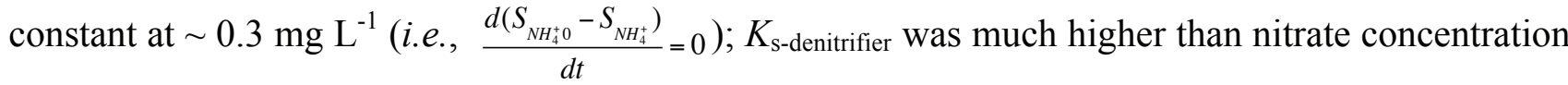
$\left(K_{\mathrm{s}-\text { denitrifier }}>>S_{\mathrm{NO} 3}\right)$, accordingly formula (4) could be simplified as equation (4-2) as follows:

$$
\frac{d S_{\mathrm{NO}_{3}^{-}}}{d t}= \begin{cases}\frac{d\left(S_{N H_{4}^{+} 0}-S_{N H_{4}^{+}}\right)}{d t}-\frac{\mu_{\max -\text { denitrifier }} S_{\mathrm{NO}_{3}^{-}} X_{0-\text { denitrifier }}}{K_{s-\text { denitrifier }}} & \text { (First Stage) } \\ \frac{\mu_{\max -\text { denitrifier }} S_{N O_{3}^{-}}\left(S_{N O_{3}^{-} 0}+X_{0-\text { denitrifier }}-S_{N O_{3}^{-}}\right)}{K_{s-\text { denitififer }}} & \text { (Second Stage) }\end{cases}
$$

the integral forms of Equations (4-1) and (4-2) are:

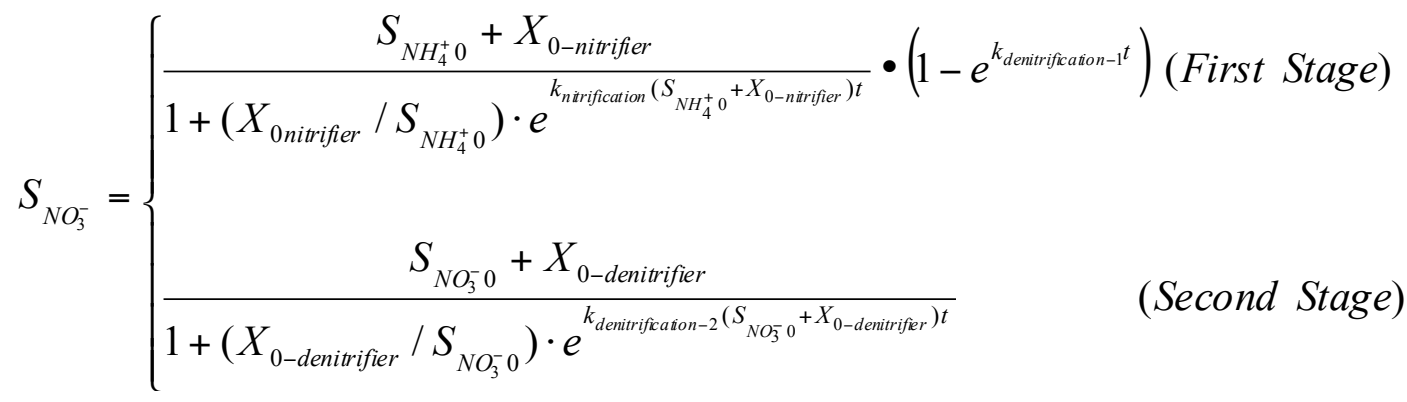
where $k_{\text {denitrification-1 }}$ is the denitrification rate constant during the first stage $\left(\mathrm{d}^{-1}\right)$, $k_{\text {denitrification-1 }}=\frac{\mu_{\text {max-denitrifier }} \cdot X_{0-\text { denitrifier }}}{K_{\text {s-denitrifier }}} ; k_{\text {denitrification-2 }}$ is the denitrification rate constant during the secon d stage $\left(\mathrm{d}^{-1}\left(\mathrm{mgL}^{-1}\right)^{-1}\right), k_{\text {denitrification-2 }}=\mu_{\text {max-denitrifier }} / K_{\text {s-denitrifier }}$.

Based on the variations of $\left[\mathrm{NO}_{3}{ }^{-}\right]$shown in Fig. 6, the kinetics of nitrate fit the equations (5-1) and $(5-2)$ very well $(p<0.01)$. According to the results shown in Table 3, the denitrification rate constant $\left(K_{\text {denitrification-1 }}\right)$ ascended with SPS concentration conforming to a power function during the first stage (Fig. S6), coinciding with the relationship between nitrification rate constant $\left(k_{\text {nitrification}}\right)$ and SPS concentration as mentioned before. It implied that the denitrification rate might be tightly related to nitrate available produced by nitrification. For the system containing $0 \mathrm{~g} \mathrm{~L}^{-1} \mathrm{SPS}$, the second stage did not occur obviously; the denitrification rate constant $\left(k_{\text {denitrification-2 }}\right)$ in systems 
containing $1,2.5,8,15$, and $20 \mathrm{~g} \mathrm{~L}^{-1}$ SPS also ascended with SPS concentration conforming to a power function $\left(\mathrm{R}^{2}=0.72\right)$ during the second stage, indicating the enhanced effect of SPS on denitrification.

\subsection{Mechanisms about the influence of SPS on CND in bed sediment-SPS-water system}

\subsubsection{Influence of SPS concentration on bacterial abundances}

The SPS's nitrifying bacteria populations increased with SPS concentration also following a power function $\left(\mathrm{R}^{2}=0.93\right.$, Fig. $\left.8 \mathrm{~A}\right)$, which was similar to the nitrification rate dependence on the SPS concentration. Nitrification rates were positively correlated to nitrifying bacteria populations in SPS $(p<0.01$, Fig. $8 \mathrm{~B})$. The nitrifying bacteria population in the bed sediment, however, was smaller than that in the SPS and did not show an obvious relationship with nitrification rate (Fig. S7). This implies that $\mathrm{NH}_{4}{ }^{+}-\mathrm{N}$ loss in the system was mainly caused by nitrification occurring on SPS, not in the bed-sediments.

For both SPS and bed-sediment, the denitrifying bacteria population increased with SPS concentration as a power function (Fig. 8C). When SPS concentration was elevated from 15 to $20 \mathrm{~g}$ $\mathrm{L}^{-1}$, the denitrifying bacteria in SPS jumped from $1.6 \times 10^{4}$ to $2.1 \times 10^{6}$ gene copies while the bed-sediment decreased from $4.9 \times 10^{5}$ to $3.0 \times 10^{4}$ gene copies. This might have been caused by abrupt increase in oxygen-limited microsites at SPS phase due to cohesions of SPS particles and the increased oxygen diffusion into the sediment caused by increasing agitation rate. Overall, when SPS concentration increased from 0 to $20 \mathrm{~g} \mathrm{~L}^{-1}$, the total denitrifying bacteria in system (bacteria in SPS plus that in bed-sediment) increased with SPS concentration and was positively related to denitrification rate $(p<0.05$, Fig. 8D). Therefore, it suggests that denitrification in systems was related to denitrifying bacteria in not only SPS but also bed-sediment.

\subsubsection{Influence of SPS concentration on denitrification in bed-sediment}

Some of the $\mathrm{NO}_{3}{ }^{-}$produced by nitrifying bacteria on SPS was subsequently reduced to $\mathrm{N}_{2}$ in oxygen-limited microsites of SPS and the remaining $\mathrm{NO}_{3}{ }^{-}$diffused into bed-sediment where it was denitrified. Therefore, the $\mathrm{NO}_{3}{ }^{-}$produced by nitrification at SPS would exert influences on the denitrification process occurring not only in SPS but also in bed-sediment phases. As shown in Fig. 
$\mathrm{S} 8$, the average removal rate of $\mathrm{NO}_{3}{ }^{-}$(including denitrification and other process) increased linearly with initial $\mathrm{NO}_{3}{ }^{-}$concentration $(\mathrm{p}<0.01$, Supplementary Section $\mathrm{S} 4)$ in bed sediment-SPS-water system, suggesting that denitrification rate was influenced by nitrate availability. According to the results shown in Fig. S9, the average CND rates were 248, 634, $1515 \mu \mathrm{g} \mathrm{m}^{-2} \mathrm{~d}^{-1}$ in systems containing only $8 \mathrm{~g} \mathrm{~L}^{-1}$ SPS, containing bed-sediment but without SPS, containing both $8 \mathrm{~g} \mathrm{~L}^{-1}$ SPS and bed-sediment, respectively. Based on our estimations (Supplementary Section S5), compared to the system with bed-sediment covered by static water, roughly $28 \%$ of the increased N-loss in bed sediment-SPS-water system was ascribed to N-loss at SPS and $72 \%$ to N-loss in bed-sediment accelerated by elevated nitrate supply produced by overlying-water nitrification which was enhanced by the presence of SPS. Because agitation, simulating the river flow and causing the presence of SPS, would pose effects on the diffusion of nitrate from water to bed-sediment, the increased nitrate supply in bed-sediment was also caused by the agitation conditions in addition to the presence of SPS itself which accelerated the production of nitrate. Since SPS concentration also depends on hydrodynamic conditions including river flow velocity in natural rivers (Xia et al., 2016), the results obtained under different agitation rates in this study can reflect the effect of SPS concentration on $\mathrm{N}-$ loss from natural rivers.

\subsection{The in-situ nitrifying and denitrifying bacteria abundances in the Yellow River}

\subsection{Importance of SPS to N loss from river systems}

As the N-loss in the incubation systems might also be caused by anammox processes in addition to denitrification, the N-loss caused by coupled nitrification-denitrification might be lower than the emission of ${ }^{15} \mathrm{~N}_{2}$ observed in the incubation experiments of the present research. However, our data 
show that SPS enhances the nitrification and denitrification processes as well as N-loss from rivers. $\mathrm{NH}_{4}{ }^{+}$and $\mathrm{NO}_{3}{ }^{-}$are the main inorganic nitrogen species in the Yellow River and Yangtze River, and they mainly come from nitrogenous fertilizer application and wastewater discharge (Xia et al., 2002; Li et al., 2010; Liu et al., 2013a), with a relatively low atmospheric deposition contribution. This is significantly different from the ocean where up to one third of the external nitrogen supply comes from the atmospheric anthropogenic fixed nitrogen (Duce et al., 2008). $\mathrm{NH}_{4}{ }^{+}$and $\mathrm{NO}_{3}{ }^{-}$can be removed through $\mathrm{CND}$, anammox, and denitrification processes in natural rivers. In the present research, although the initial $\mathrm{NH}_{4}^{+}$concentration was much higher while $\mathrm{NO}_{3}{ }^{-}$concentration was much lower than their concentrations in natural rivers, respectively, the results showed that the SPS can enhance CND as well as N-loss from rivers if $\mathrm{N}$ exists as $\mathrm{NH}_{4}{ }^{+}$. In addition, our previous study showed that if $\mathrm{N}$ exists as $\mathrm{NO}_{3}^{-}, \mathrm{N}$ loss through denitrification increases with the SPS concentration as well (Liu et al., 2013b). Therefore, according to the results of this study and our previous study, it is suggested that the total N-loss in the Yellow River and the Yangtze River will increase with the SPS concentration. However, more research should be carried out to study the effect of SPS on $\mathrm{N}-$ loss in natural river systems.

Based on the ${ }^{15} \mathrm{~N}_{2}$ emission rate in the SPS-water system obtained in this study, the CND rate is estimated at $730 \mathrm{~kg}-\mathrm{N} / \mathrm{km}^{2} \cdot \mathrm{yr}\left(\frac{200 \mathrm{mg} / \mathrm{m}^{2} \cdot \mathrm{d} \times 365 \mathrm{~d} \times 200 \mathrm{~cm}}{20 \mathrm{~cm}}=730 \mathrm{~kg} \mathrm{~N} / \mathrm{km}^{2} \cdot \mathrm{yr}\right)$ for rivers with $1 \mathrm{~g} \mathrm{~L}^{-1} \mathrm{SPS}$ and a depth of two meters. Previous study reported that denitrification occurring in river networks (including continental shelf, terrestrial, oceanic oxygen minimum zones, groundwater, rivers, lakes, and estuaries globally) has an average denitrification rate of 0 to $2173 \mathrm{~kg}-\mathrm{N} / \mathrm{km}^{2} \cdot \mathrm{yr}$ (Seitzinger et al., 2006). This is at comparable scales to the N-loss caused by CND occurring on SPS in the present study, suggesting that CND on SPS can not be neglected in river N removal."

We defined the increased proportion of $\mathrm{N}-\operatorname{loss}\left(\Delta \%_{\mathrm{Nloss}}\right)$ caused by SPS as follows:

$$
\Delta \%_{\text {Nloss }}=\frac{\mathrm{N}_{\text {loss }} \text { in BS-SPS-WS containing SPS }-\mathrm{N}_{\text {loss }} \text { in BS-WS without SPS }}{\mathrm{N}_{\text {loss }} \text { in BS-WS without SPS }} \times 100
$$

If SPS concentration was assumed to be $1 \mathrm{~g} \mathrm{~L}^{-1}$, the $\Delta \%_{\text {Nloss }}$ in the samples collected from the HYK, LM, AS, WZ, and 37-Dock location were $25 \%, 53 \%, 53 \%, 80 \%$, and $122 \%$, respectively; they were positively related to the TOC of SPS (Fig. S10). The above results indicate that the accelerated effect 
of SPS on N-loss was impacted by both concentration and properties of SPS. In addition, according to the above results, the increased proportion of N loss caused by SPS reached $100 \%$ when SPS concentration increased to $1 \mathrm{~g} \mathrm{~L}^{-1}$ in the Yangtze River (TOC $\approx 0.64 \%$ ). Approximately $46 \%$ of the rivers around the world has SPS concentration higher than $1 \mathrm{~g} \mathrm{~L}^{-1}$ (Xia et al., 2016), and the TOC content in most of these rivers are higher than that in the Yangtze River (Table S4), thus the nitrogen loss in these rivers might increase at least by one time due to the presence of SPS.

The importance of water column processes becomes increasingly remarkable with the increase of stream size according to the river continuum concept (Vannote et al., 1980), and Reisinger et al. (2015) also reported that the water column nutrient uptake including assimilation and dissimilatory transformation increase with stream size. Therefore, for the large rivers of the world, where the interaction between the water column and the bed sediment is limited, coupled nitrification-denitrification and other nitrogen transformation processes in the overlying water containing SPS will act as a crucial role in nitrogen loss in river systems. Traditional frameworks of global $\mathrm{N}$ cycle have not considered coupled nitrification-denitrification and other processes occurring on SPS, leading to an underestimation of N-loss from rivers, especially for the large rivers. The observation of the present research is consistent with recent research that the estimated global $\mathrm{N}$ budget is out of balance, with inputs exceeding losses (Galloway et al., 2004; Schlesinger, 2009). Therefore, the enhanced effect of SPS on N-loss from rivers need to be factored into the new generation model of $\mathrm{N}$ cycle. Because spatio-temporal and vertical variations in SPS concentration and composition exist for each river (Bouchez et al., 2011a, 2011b; Xia et al., 2016), more research should be conducted to estimate the contribution of water column containing SPS to N-loss in rivers by considering the SPS concentration and composition as well as other environmental conditions and climatic factors including temperature. In addition, the linkage between SPS and emission of $\mathrm{N}_{2} \mathrm{O}$, an important greenhouse gas produced by nitrification/denitrification, should be examined to determine the role of SPS in nitrogen cycle under the context of climate change.

\section{Conclusion}

Taking the Yellow and Yangtze Rivers as examples, this study demonstrates that SPS, a major component of rivers, is a hot spot for both nitrification and denitrification through simulation 
experiments and in-situ investigation. CND could occur on SPS in oxic waters because of the presence of oxic and anoxic/low oxygen microsites around SPS; the nitrogen loss rate $\left(R_{N-\text { loss }}\right)$ increased with SPS concentration $([S P S])$ as a power function $\left(R_{N-\text { loss }}=a^{*}[S P S]^{b}\right)$. The influencing mechanisms of SPS on CND rate have been analyzed; the nitrifying and denitrifying bacteria population was elevated with SPS concentration conforming to a power function for both the lab simulation experiments and in-situ investigation of the Yellow River. This study suggests that $1 \mathrm{~g} \mathrm{~L}^{-1}$ SPS will lead to an enhancement in nitrogen loss by approximately $25 \sim 120 \%$ in the Yellow and Yangtze Rivers, and the enhancement increases with organic carbon content (TOC) of SPS. Thus $\mathrm{N}$-loss from rivers in previous studies might be underestimated due to non consideration of the presence of SPS; this may partially compensate for the current disequilibrium between $\mathrm{N}$ inputs and $\mathrm{N}$ sinks. The future $\mathrm{N}$ research regarding SPS needs to aim at estimating the role of SPS more accurately by considering other nitrogen transformation processes, and the SPS concentration and composition as well as other environmental conditions.

\section{Acknowledgements}

This work was financially supported by the National Natural Science Foundation of China (91547207), the National Science Foundation for Distinguished Young Scholars (51325902), and the National Natural Science Foundation for Innovative Research Group (51421065).

\section{References}

Abril G., Commarieu M.-V., Etcheber H., Deborde J., Deflandre B., Živađinović M.K., Chaillou G. and Anschutz, P., 2010. In vitro simulation of oxic/suboxic diagenesis in an estuarine fluid mud subjected to redox oscillations. Estuar. Coast. Shelf Sci. 88, 279-291.

Abril G., Riou S., Etcheber H., Frankignoulle M., De Wit R. and Middelburg J., 2000. Transient, tidal time-scale, nitrogen transformations in an estuarine turbidity maximum - fluid mud system (The Gironde, South-west France). Estuar. Coast. Shelf Sci. 50, 703-715.

Berounsky V.M. and Nixon S.W., 1993. Rates of nitrification along an estuarine gradient in Narragansett Bay. Estuaries $16,718-730$.

Bianchi M., Marty D., Teyssie J.L. and Fowler S.W., 1992. Strictly Aerobic and Anaerobic-Bacteria Associated with Sinking Particulate Matter and Zooplankton Fecal Pellets. Mar. Ecol. Prog. Ser. 88, 55-60.

Billi P. and Ali O.E., 2010. Sediment transport of the Blue Nile at Khartoum. Quatern. Int. 226, 12-22.

Bouchez J., Lupker M., Gaillardet J., France-Lanord C. and Maurice L., 2011a. How important is it to integrate riverine suspended sediment chemical composition with depth? Clues from Amazon River depth-profiles. Geochim. 
Cosmochim. Acta 75, 6955-6970.

Bouchez J., Métivier F., Lupker M., Maurice L., Perez M., Gaillardet J. and France-Lanord C., 2011b. Prediction of depth-integrated fluxes of suspended sediment in the Amazon River: Particle aggregation as a complicating factor. Hydrol. Process 25, 778-794.

Boyer E.W., Howarth R.W., Galloway J.N., Dentener F.J., Green P.A. and Vörösmarty C.J., 2006. Riverine nitrogen export from the continents to the coasts. Glob. Biogeochem. Cycle 20, 1-91.

Changjiang Water Resources Committee (2014) Changjiang Sediment Bulletin. Ministry of Water Resources, Wuhan, 430012, China.

Cochran W. G., 1950. Estimation of Bacterial Densities by Means of the Most Probable Number. Biometrics 6, 105-116.

Dale O.R., Tobias C.R. and Song B., 2009. Biogeographical distribution of diverse anaerobic ammonium oxidizing (anammox) bacteria in Cape Fear River Estuary. Environ. Microbiol. 11, 1194-1207.

Diaz, R.J, and Rosenberg, R. 2008. Spreading dead zones and consequences for marine ecosystems. Science 321:926-929

Donner S.D. and Kucharik C. J., 2008. Corn-based ethanol production compromises goal of reducing nitrogen export by the Mississippi River. P. Natl. Acad. Sci. USA 105, 4513-4518.

Duce R.A., LaRoche J., Altieri K. et al., 2008. Impacts of atmospheric anthropogenic nitrogen on the open ocean, Science 320, 893-897

Falkowski P.G., Fenchel T., and Delong E.F., 2008. The microbial engines that drive Earth's biogeochemical cycles. Science 320, 1034-1039.

Galloway J.N., 1998. The global nitrogen cycle: changes and consequences. Environ. Pollut.102, 15-24.

Galloway J.N., Dentener F.J., Capone D.G., Boyer E.W., Howarth R.W., Seitzinger S.P., Asner G.P., Cleveland C.C., Green P.A., Holland E.A., Karl D.M., Michaels A.F., Porter J.H., Townsend A.R. and Vorosmarty C.J., 2004. Nitrogen cycles: past, present, and future. Biogeochemistry 70, 153-226.

Gruber N., Galloway J.N., 2008. An Earth-system perspective of the global nitrogen cycle. Nature 451, 293-296.

Helder W.and De Vries R., 1983. Estuarine nitrite maxima and nitrifying bacteria (Ems-Dollard estuary). Neth. J. Sea Res. $17,1-18$.

Hsiao S.S.Y., Hsu T.C., Liu J.W., Xie X., Zhang Y., Lin J., Wang H., Yang J.Y.T., Hsu S.C., Dai M. and Kao S.J., 2014. Nitrification and its oxygen consumption along the turbid Chang Jiang River plume. Biogeosciences 11, $2083-2098$.

Jaffe L. F. and Nuccitelli R., 1974. An ultrasensitive vibrating probe for measuring steady extracellular currents. J. Cell Biol. 63, 614-628.

Jia Z.M., Liu T., Xia X.H. and Xia N., 2016. Effect of particle size and composition of suspended sediment on denitrification in river water. Sci. Total Environ.541, 934-940.

Johannsen A., Dähnke K. and EmeisK., 2008. Isotopic composition of nitrate in five German rivers discharging into the North Sea. Org. Geochem. 39, 1678-1689.

Lamontag.Ra, Swinnert.Jw, Linnenbo.Vj and Smith W. D., 1973. Methane Concentrations in Various Marine Environments. J. Geophys. Res.78, 5317-5324.

Lansdown K, McKew BA, Whitby C, Heppell CM, Dumbrell AJ, Binley A, et al., 2016. Importance and controls of anaerobic ammonium oxidation influenced by riverbed geology. Nat. Geosci. 9, 357-360.

Lenihan H.S. and Peterson C. H., 1998. How habitat degradation through fishery disturbance enhances impacts of hypoxia on oyster reefs. Ecol. Appl. 8, 128-140.

Li S. L., Liu C. Q., Li J., Liu X., Chetelat B., Wang B., and Wang F., 2010. Assessment of the sources of nitrate in the 
Liu T., Wang F., Michalski G., Xia X.and Liu S., 2013a. Using ${ }^{15} \mathrm{~N},{ }^{17} \mathrm{O}$, and ${ }^{18} \mathrm{O}$ to determine nitrate sources in the Yellow River, China. Environ. Sci. Technol. 47, 13412-13421.

Liu T., Xia X.H., Liu S. D., Mou X. L. and Qiu Y. W., 2013b. Acceleration of denitrification in turbid rivers due to denitrification occurring on suspended sediment in oxic waters. Environ. Sci. Technol. 47, 4053-4061.

Liu X.D., Tiquia S.M., Holguin G., Wu L.Y., Nold S.C., Devol A.H., Luo K., Palumbo A.V., Tiedje J.M. and Zhou J.Z., 2003. Molecular diversity of denitrifying genes in continental margin sediments within the oxygen-deficient zone off the Pacific coast of Mexico. Appl. Environ. Microb. 69, 3549-3560.

Mallin M.A., Johnson V.L., Ensign S.H. and MacPherson T.A., 2006. Factors contributing to hypoxia in rivers, lakes, and streams. Limnol. Oceanogr. 51, 690-701.

Michotey V. and Bonin P., 1997. Evidence for anaerobic bacterial processes in the water column: denitrification and dissimilatory nitrate ammonification in the northwestern Mediterranean Sea. Mar. Ecol. Prog. Ser.160, 47-56.

Mulder T. and Syvitski J.P.M., 1995. Turbidity Currents Generated at River Mouths during Exceptional Discharges to the World Oceans. J. Geol.103, 285-299.

Mulholland P.J., Helton A.M., Poole G.C., Hall R.O., Hamilton S.K., Peterson B.J., Tank J.L., Ashkenas L.R., Cooper L W., and Dahm C.N., 2008. Stream denitrification across biomes and its response to anthropogenic nitrate loading. Nature 452, 202-205.

O'Connor B.L. and Hondzo M., 2007. Enhancement and inhibition of denitrification by fluid-flow and dissolved oxygen flux to stream sediments. Environ. Sci. Technol.42, 119-125.

Owens N. J., 1986. Estuarine nitrification: a naturally occurring fluidized bed reaction? Estuar. Coast. Shelf S. 22, 31-44.

Pina-Ochoa E. and Álvarez-Cobelas M., 2006. Denitrification in aquatic environments: a cross-system analysis. Biogeochemistry 81, 111-130.

Rabalais N. N., 2002. Nitrogen in aquatic ecosystems. Ambio. 31, 102-112.

Rao A.M., McCarthy M.J., Gardner W.S. and Jahnke R. A., 2008. Respiration and denitrification in permeable continental shelf deposits on the South Atlantic Bight: $\mathrm{N}_{2}$ : Ar and isotope pairing measurements in sediment column experiments. Cont. Shelf Res. 28, 602-613.

Reisinger A.J., Tank J.L., Rosi-Marshall E.J., Hall Jr R.O. and Baker M. A., 2015. The varying role of water column nutrient uptake along river continua in contrasting landscapes. Biogeochemistry 125, 115-131.

Reisinger, A.J., Tank, J.L, Hoellein, T.J., and Hall, R.O. 2016. Sediment, water column, and open-channel denitrification in rivers measured using membrane-inlet mass spectrometry. Journal of Geophysical Research: Biogeosciences 121:1258-1274.

Revsbech N.P., 1989. An Oxygen Microsensor with a Guard Cathode. Limnol. Oceanogr. 34, 474-478.

Roberts K.L., Kessler A.J., Grace M.R. and Cook P. L., 2014. Increased rates of dissimilatory nitrate reduction to ammonium (DNRA) under oxic conditions in a periodically hypoxic estuary.Geochim. Cosmochim. Acta 133, 313-324.

Rotthauwe J.H., Witzel K. P. and Liesack W., 1997. The ammonia monooxygenase structural gene amoA as a functional marker: Molecular fine-scale analysis of natural ammonia-oxidizing populations. Appl. Environ. Microb. 63, 4704-4712.

Schlesinger W. H., 2009. On the fate of anthropogenic nitrogen. P. Natl. Acad. Sci. USA 106, 203-208. 
Sebilo M., Billen G., Mayer B., Billiou D., Grably M., Garnier J. and Mariotti A., 2006. Assessing nitrification and denitrification in the Seine River and estuary using chemical and isotopic techniques. Ecosystems 9, 564-577.

Seitzinger S.P., 1988. Denitrification in freshwater and coastal marine ecosystems: ecological and geochemical significance. Limnol. Oceanogr. 33, 702-724.

Seitzinger, S.P, Harrison, J. A., Böhlke, J., Bouwman, A., Lowrance, R., Peterson, B., Tobias, C., Drecht, G. V., 2006. Denitrification across landscapes and waterscapes: a synthesis. Ecol. Appl. 16, (6), 2064-2090.

Sivakumar B., 2002. A phase-space reconstruction approach to prediction of suspended sediment concentration in rivers. J. Hydrol.258, 149-162.

Smith P., 1995. Non-invasive ion probes--tools for measuring transmembrane ion flux. Nature 378, 645.

Turner R.E. and RabalaisN. N., 1994. Coastal eutrophication near the Mississippi river delta. Nature 368, 619-621.

Vannote R.L., Minshall G.W., Cummins K.W., Sedell J.R. and Cushing C. E., 1980. The river continuum concept. Can. J. Fish. Aquat. Sci.37, 130-137.

Venterink H.O., Hummelink E. and Van den Hoorn M. W., 2003. Denitrification potential of a river floodplain during flooding with nitrate-rich water: grasslands versus reedbeds. Biogeochemistry 65, 233-244.

Wang S., Zhu G., Peng Y., Jetten M.S. and YinC., 2012. Anammox bacterial abundance, activity, and contribution in riparian sediments of the Pearl River estuary. Environ. Sci. Technol. 46, 8834-8842.

Water Conservancy Committee of the Yellow River (2013). Yellow River Sediment Bulletin. The Yellow River Public House of the Water Resources, Zhengzhou, China.

Xia X., Dong J., Wang M., Xie H., Xia N., Li H., Zhang X., Mou X., Wen J. and Bao Y., 2016. Effect of water-sediment regulation of the Xiaolangdi reservoir on the concentrations, characteristics, and fluxes of suspended sediment and organic carbon in the Yellow River. Sci Total Environ. 571, 487-497

Xia X., Yang Z. and Zhang X., 2009. Effect of suspended-sediment concentration on nitrification in river water: importance of suspended sediment-water interface. Environ. Sci. Technol. 43, 3681-3687.

Xia X.H., Liu T., Yang Z.F., Zhang X.Q. and Yu Z.B., 2013. Dissolved organic nitrogen transformation in river water: Effects of suspended sediment and organic nitrogen concentration. J. Hydrol. 484, 96-104.

Xia X.H., Yang Z.F., Huang G.H., Zhang X.Q., Yu H. and Rong X., 2004. Nitrification in natural waters with high suspended-solid content - A study for the Yellow River. Chemosphere 57, 1017-1029.

Xia X.H., Zhou J.S. and Yang Z. F., 2002. Nitrogen contamination in the Yellow River basin of China. J. Environ. Qual. $31,917-925$.

Zhang Y., Xie X., Jiao N., Hsiao S. Y. and Kao S. J., 2014. Diversity and distribution of amoA-type nitrifying and nirS-type denitrifying microbial communities in the Yangtze River Estuary. Biogeosciences 11, 2131-2145.

Zhu G., Wang S., Zhou L., Wang Y., Zhao S., Xia C., Wang W., Zhou R., Wang C. and Jetten M.S., 2015. Ubiquitous anaerobic ammonium oxidation in inland waters of China: an overlooked nitrous oxide mitigation process. Scientific reports 5 . 
Table 1 Summary of sediment characteristics at the five sampling sites of the Yellow River and the Yangtze River

\begin{tabular}{cccccccc}
\hline \multirow{2}{*}{ Site name } & River & \multicolumn{4}{c}{ Particle Size (\%) } & TOC & $\begin{array}{c}\text { Total organic } \\
\text { nitrogen }\end{array}$ \\
\cline { 3 - 6 } & & $<20 \mu \mathrm{m}$ & $20-50 \mu \mathrm{m}$ & $50-100 \mu \mathrm{m}$ & $>100 \mu \mathrm{m}$ & $(\%)$ & $(\%)$ \\
\hline Huayuankou & the Yellow River & 2.9 & 22.8 & 37.5 & 19.9 & 0.167 & 0.02 \\
Longmen & the Yellow River & 4.0 & 24.9 & 50.8 & 15.8 & 0.186 & 0.01 \\
Aishan & the Yellow River & 23.2 & 46.4 & 25.1 & 4.3 & 0.215 & 0.02 \\
37-Dock & the Yangtze River & 23.0 & 18.6 & 35.9 & 16.0 & 0.599 & 0.05 \\
Wanzhou & the Yangtze River & 55.7 & 17.4 & 12.7 & 6.1 & 0.668 & 0.06 \\
\hline
\end{tabular}


Table 2 Incubation experiment conditions

\begin{tabular}{|c|c|c|c|c|c|}
\hline Research purpose & System composition & $\begin{array}{l}{ }^{15} \mathrm{NH}_{4}^{+}-\mathrm{N} \\
\left(\mathrm{mg} \mathrm{L}^{-1}\right)\end{array}$ & $\begin{array}{l}\mathrm{NO}_{3}{ }^{-}-\mathrm{N} \\
\left(\mathrm{mg} \mathrm{L}^{-1}\right)\end{array}$ & $\begin{array}{c}\text { SPS } \\
\text { concentration } \\
\left(\mathrm{g} \mathrm{L}^{-1}\right)\end{array}$ & $\begin{array}{c}\text { Particle } \\
\text { Size of SPS } \\
(\mu \mathrm{m})\end{array}$ \\
\hline $\begin{array}{c}\text { Occurrence of CND } \\
\text { at SPS }\end{array}$ & $\begin{array}{c}\text { SPS + water } \\
(\text { samples from site AS) }\end{array}$ & 5 & 0 & $\begin{array}{c}0 \\
1 \\
2.5 \\
8 \\
15 \\
20 \\
\end{array}$ & $\begin{array}{c}\text { Homogenized } \\
\text { sediment }\end{array}$ \\
\hline $\begin{array}{l}\mathrm{O}_{2} \text { flux and profile } \\
\text { around SPS particle }\end{array}$ & $\begin{array}{c}\text { SPS + water } \\
(\text { samples from site AS) }\end{array}$ & $\begin{array}{c}5 \\
\left(\mathrm{NH}_{4}^{+}-\mathrm{N}\right)\end{array}$ & 0 & 20 & $\begin{array}{c}<20 \\
20 \sim 50 \\
50 \sim 100 \\
>100 \\
\end{array}$ \\
\hline $\begin{array}{c}\text { Effect of SPS } \\
\text { concentration on CND } \\
\text { in BS-SPS-WS }\end{array}$ & $\begin{array}{c}\text { bed-sediment }+ \text { SPS } \\
\text { +water } \\
\text { (samples from sites HYK, } \\
\text { LM, AS, 37-Dock, and } \\
\text { WZ) }\end{array}$ & 5 & 0 & $\begin{array}{c}0 \\
1 \\
2.5 \\
8 \\
15 \\
20 \\
\end{array}$ & $\begin{array}{l}\text { homogenized } \\
\text { sediment }\end{array}$ \\
\hline $\begin{array}{l}\text { Effect of initial nitrate } \\
\text { concentration on } \\
\text { denitrification in } \\
\text { BS-SPS-WS }\end{array}$ & $\begin{array}{c}\text { bed-sediment }+ \text { SPS } \\
+ \text { water } \\
(\text { samples from site HYK) }\end{array}$ & 0 & $\begin{array}{c}1 \\
3 \\
4.5 \\
6 \\
10 \\
\end{array}$ & 8 & $\begin{array}{l}\text { homogenized } \\
\text { sediment }\end{array}$ \\
\hline CND in BS-WS & $\begin{array}{l}\text { bed-sediment }+ \text { water } \\
(\text { samples from site AS) }\end{array}$ & 5 & 0 & 0 & $\begin{array}{c}\text { homogenized } \\
\text { sediment }\end{array}$ \\
\hline
\end{tabular}


Table 3 Nitrification and denitrification rate constants in bed sediment-SPS-water systems for samples collected from site HYK of the Yellow River

\begin{tabular}{|c|c|c|c|}
\hline $\begin{array}{c}\text { SPS } \\
\text { concentration } \\
\left(\mathrm{g} \mathrm{L}^{-1}\right) \\
\end{array}$ & $\begin{array}{l}\text { nitrification rate constant } \\
\left(k_{\text {nitrification, }}\left(\mathrm{mg} \mathrm{L}^{-1}\right)^{-1} \mathrm{~d}^{-1}\right)\end{array}$ & $\begin{array}{c}\text { denitrification rate } \\
\text { constant in the first stage } \\
\left(k_{\left.\text {denitrification- } 1, \mathrm{~d}^{-1}\right)}\right.\end{array}$ & 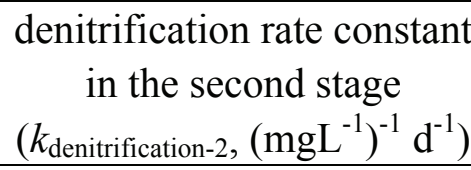 \\
\hline 0 & 0.013 & 0.015 & I \\
\hline 1 & 0.023 & 0.034 & 0.0203 \\
\hline 2.5 & 0.048 & 0.063 & 0.0278 \\
\hline 8 & 0.053 & 0.075 & 0.0281 \\
\hline 15 & 0.054 & 0.081 & 0.0298 \\
\hline 20 & 0.057 & 0.079 & 0.0290 \\
\hline
\end{tabular}


Figure 1 The sampling sites of the Yellow River and the Yangtze River. Red triangles mark sampling sites for simulation experiments (Y8: Longmen $=\mathrm{LM}, \mathrm{Y} 11$ : Huayuankou $=$ HYK, Y14: Aishan = AS; C1: Wanzhou $=$ WZ, C2: 37-Dock), and black circles represent locations for investigation of in-situ bacteria abundances (Y1: Lanzhou, Y2: Xiaheyan, Y3: Qingtongxia, Y4: Shizuishan, Y5: Sanhuhekou, Y6: Toudaoguai, Y7: Wubao, Y9: Tongguan, Y10: Sanmenxia, Y12: Kaifeng, Y13: Gaocun, Y15: Luokou, Y16: Lijin, Y17: Kenli).

Figure 2 Influence of suspended sediment concentration on ${ }^{15} \mathrm{~N}_{2}$ emission (A), population of nitrifying and denitrifying bacteria (B) in suspended sediment-water system at the end of incubation (26 days). Data represent the average of three replicates $\pm \mathrm{SD}$; the $\mathrm{a}, \mathrm{b}, \mathrm{c}$ and $\mathrm{a}^{\prime}, \mathrm{b}^{\prime}, \mathrm{c}^{\prime}$ in (B) mean the significant differences among the 6 groups based on Duncan's multiple range test, respectively.

Figure 3 Net $\mathrm{O}_{2}$ flux (A) and $\mathrm{O}_{2}$ gradient (B) around suspended sediment particles in relation to the distance from near the surface of SPS particle. Note: J indicates the flux ( $p$ mol cm $\mathrm{cm}^{-2} \mathrm{~s}^{-1}$ ) negative values of net $\mathrm{O}_{2}$ flux in (A) indicate net influxes; negative values of distance in (B) indicate the distance away from particle surface in bulk solution, and positive values of distance in (B) indicate the distance away from particle surface within particle. Oxygen levels of $53 \%$ and $70 \%$ air saturation represented the levels where facultative bacteria, which were identified as Alcaligenes faecalis and Paracoccus denitrificans on the SPS in the Yellow River, can conduct denitrification (Liu et al., 2013).

Figure 4 Effect of suspended sediment concentration on the ${ }^{15} \mathrm{~N}_{2}$ production from ${ }^{15} \mathrm{NH}_{4}{ }^{+} \mathrm{N}$ in bed sediment-suspended sediment-water system (BS-SPS-WS) for samples collected from site HYK of the Yellow River. Data represent the average of three replicates, and the standard deviation is less than $10 \%$. Note: The effect of SPS concentration on ${ }^{15} \mathrm{~N}_{2}$ production for samples from site AS, WZ, LM, 37-Dock is shown in Figure S4.

Figure 5 Power functional relationship between suspended sediment concentration and production rate of ${ }^{15} \mathrm{~N}_{2}$ from ${ }^{15} \mathrm{NH}_{4}{ }^{+}-\mathrm{N}$ in bed sediment-suspended sediment-water 
664

665

666

667

668

669

670

671

672

673

674

675

676

677

678

679

680

681

682

683

684

system (BS-SPS-WS) for samples collected from different sites of the Yellow River and the Yangtze River, respectively. Data represent the average of three replicates \pm SD.

Figure 6 Variations of $\mathrm{NH}_{4}^{+}, \mathrm{NO}_{3}^{-}, \mathrm{NO}_{2}^{-}$, and $\mathrm{N}_{2}$ in bed sediment-suspended sediment-water system (BS-SPS-WS) containing different concentrations of suspended sediment for samples collected from site HYK of the Yellow River. Data represent the average of three replicates, and the standard deviation is less than $10 \%$.

Figure 7 Variation of $\mathrm{NH}_{4}{ }^{+}-\mathrm{N}$ concentration with time and its fitting with the Logistic model (A), and the relation of nitrification rate constants with suspended sediment concentration (B) in bed sediment-suspended sediment-water system (BS-SPS-WS) for samples collected from site HYK. Data represent the average of three replicates \pm SD.

Figure 8 Relationship between SPS concentration and nitrifying bacteria population (A), between nitrification rate constant and nitrifying bacteria population (B), between suspended sediment concentration and denitrifying bacteria population (C), and between average denitrification rate and denitrifying bacteria population (D) in bed sediment-suspended sediment-water system (BS-SPS-WS) for samples collected from site HYK.

Figure 9 The in-situ nitrifying and denitrifying bacteria population in water samples (containing suspended sediment) collected from the Yellow River (15 sites) 


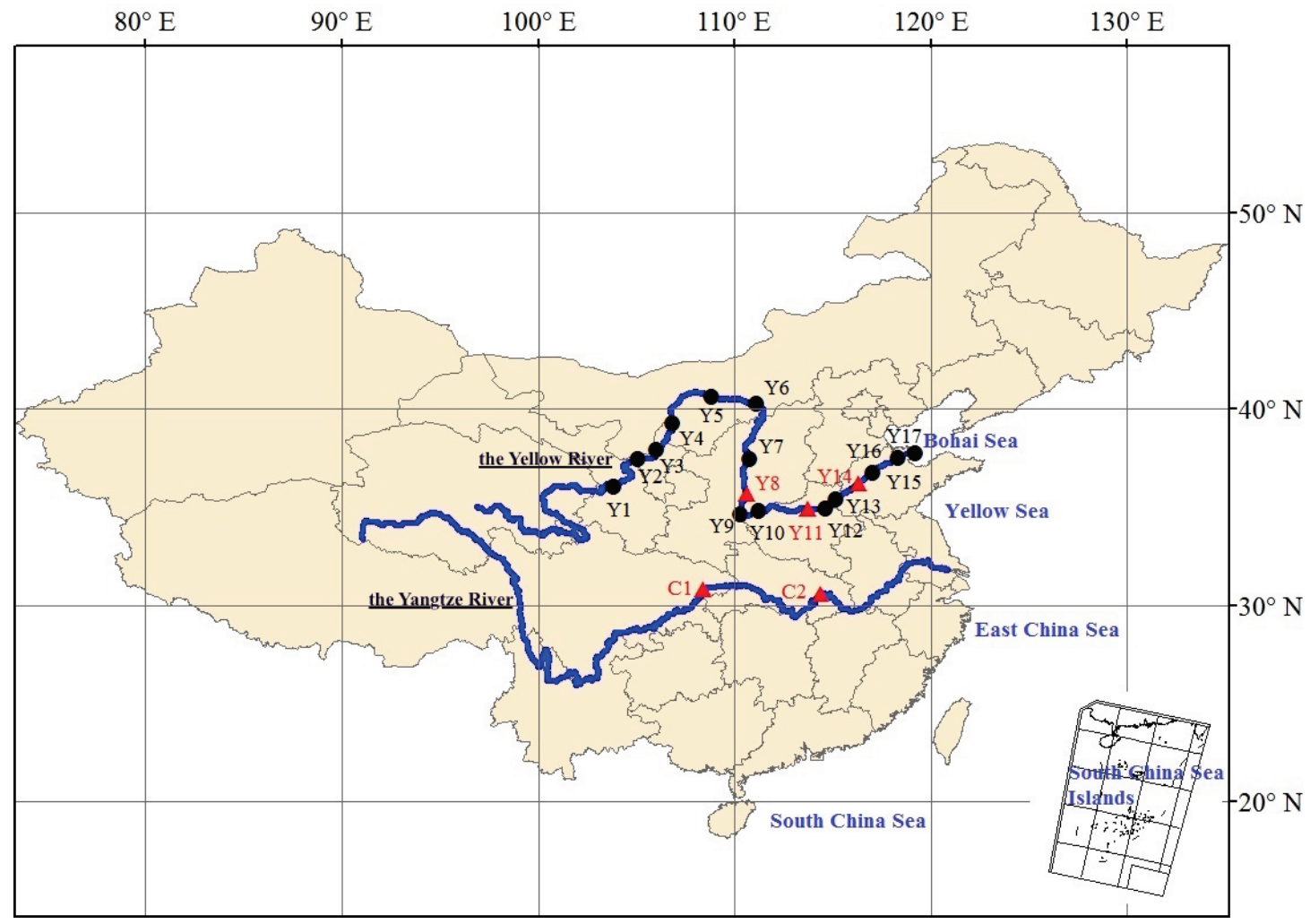

Figure 1 The sampling sites of the Yellow River and the Yangtze River. Red triangles mark sampling sites for simulation experiments (Y8: Longmen $=\mathrm{LM}, \mathrm{Y} 11$ : Huayuankou $=$ HYK, Y14: Aishan $=$ AS; C1: Wanzhou $=$ WZ, C2: 37-Dock), and black circles represent locations for investigation of in-situ bacteria abundances (Y1: Lanzhou, Y2: Xiaheyan, Y3: Qingtongxia, Y4: Shizuishan, Y5: Sanhuhekou, Y6: Toudaoguai, Y7: Wubao, Y9: Tongguan, Y10: Sanmenxia, Y12: Kaifeng, Y13: Gaocun, Y15: Luokou, Y16: Lijin, Y17: Kenli). 

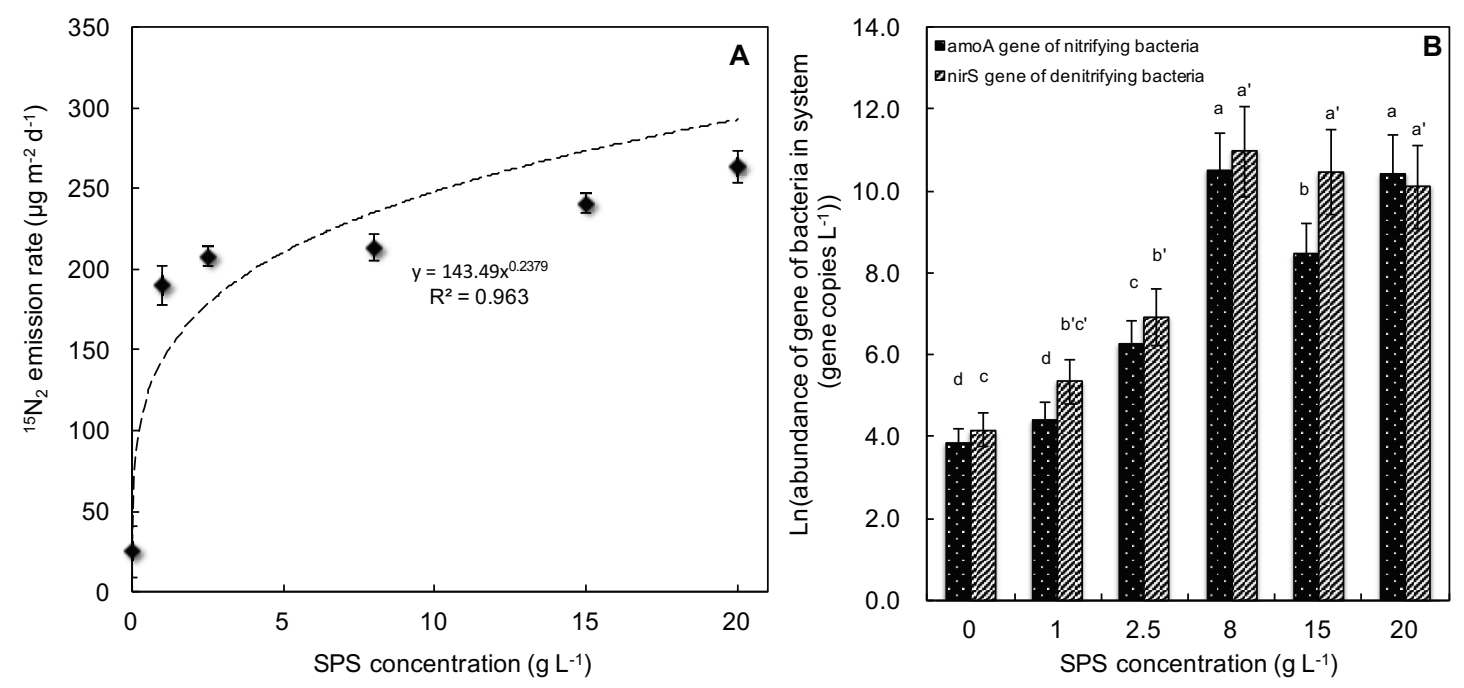

696

697

Figure 2 Influence of suspended sediment concentration on ${ }^{15} \mathrm{~N}_{2}$ emission (A), population of nitrifying and denitrifying bacteria (B) in suspended sediment-water system at the end of incubation (26 days). Data represent the average of three replicates $\pm \mathrm{SD}$; the $\mathrm{a}, \mathrm{b}, \mathrm{c}$ and $\mathrm{a}^{\prime}, \mathrm{b}^{\prime}, \mathrm{c}^{\prime}$ in (B) mean the significant differences among the 6 groups based on Duncan's multiple range test, respectively. 


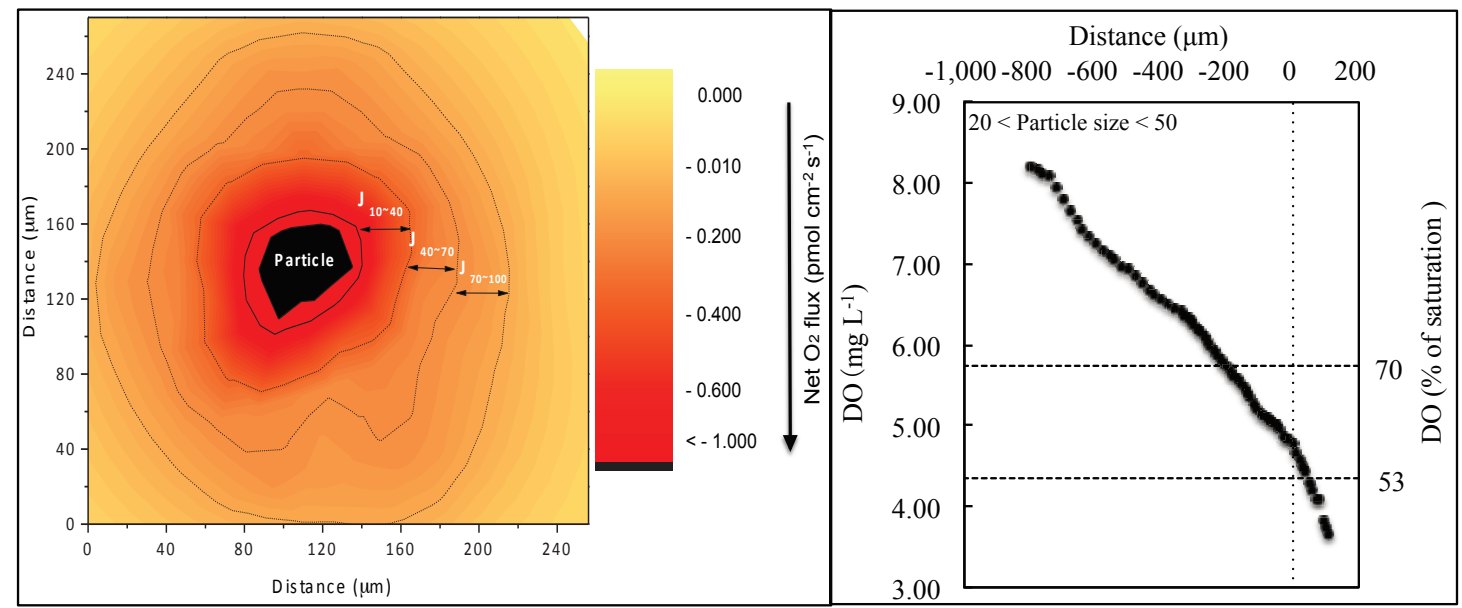

Figure 3 Net $\mathrm{O}_{2}$ flux (A) and $\mathrm{O}_{2}$ gradient (B) around suspended sediment particles in relation to the distance from near the surface of SPS particle. Note: J indicates the flux ( $p$ mol cm $\mathrm{cm}^{-2} \mathrm{~s}^{-1}$ ); negative values of net $\mathrm{O}_{2}$ flux in (A) indicate net influxes; negative values of distance in (B) indicate the distance away from particle surface in bulk solution, and positive values of distance in (B) indicate the distance away from particle surface within particle. Oxygen levels of $53 \%$ and $70 \%$ air saturation represented the levels where facultative bacteria, which were identified as Alcaligenes faecalis and Paracoccus denitrificans on the SPS in the Yellow River, can conduct

712 denitrification (Liu et al., 2013). 


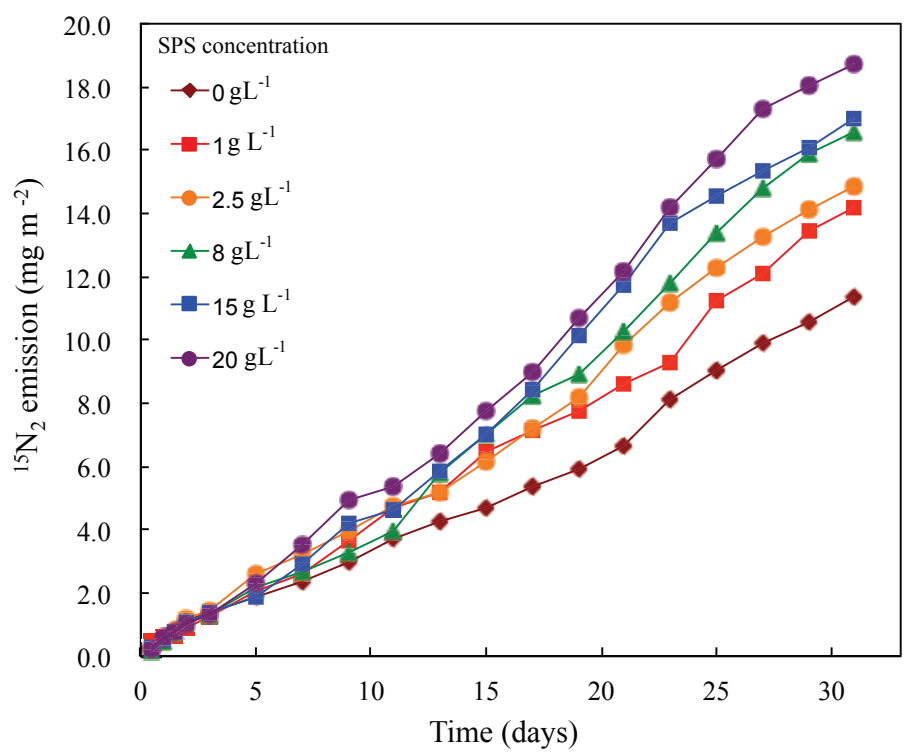

Figure 4 Effect of suspended sediment concentration on the ${ }^{15} \mathrm{~N}_{2}$ production from ${ }^{15} \mathrm{NH}_{4}{ }^{+}-\mathrm{N}$ in bed sediment-suspended sediment-water system (BS-SPS-WS) for samples collected from site HYK of the Yellow River. Data represent the average of three replicates, and the standard deviation is less than $10 \%$. Note: The effect of SPS concentration on ${ }^{15} \mathrm{~N}_{2}$ production for samples from site AS, WZ, LM, 37-Dock is shown in Figure S4. 


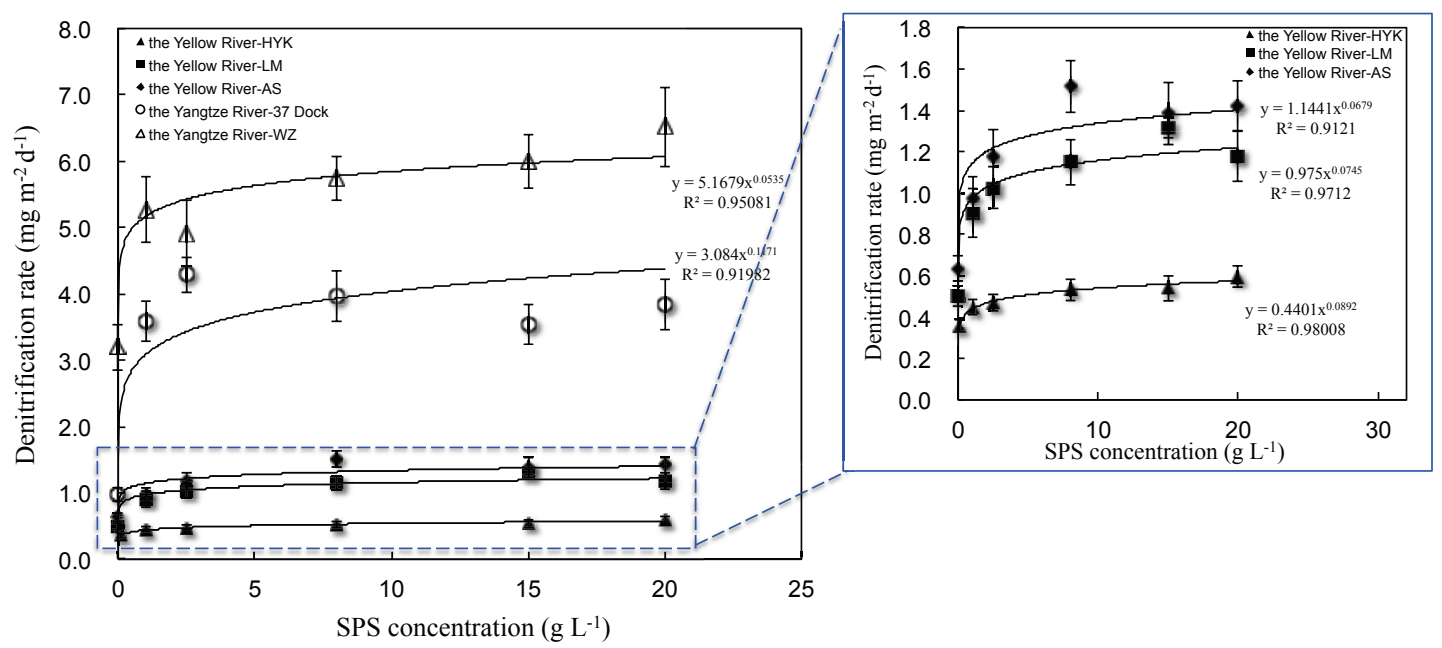

738 Figure 5 Power functional relationship between suspended sediment concentration and production 739 rate of ${ }^{15} \mathrm{~N}_{2}$ from ${ }^{15} \mathrm{NH}_{4}{ }^{+} \mathrm{N}$ in bed sediment-suspended sediment-water system (BS-SPS-WS) for 740 samples collected from different sites of the Yellow River and the Yangtze River, respectively. Data 741 represent the average of three replicates $\pm \mathrm{SD}$. 

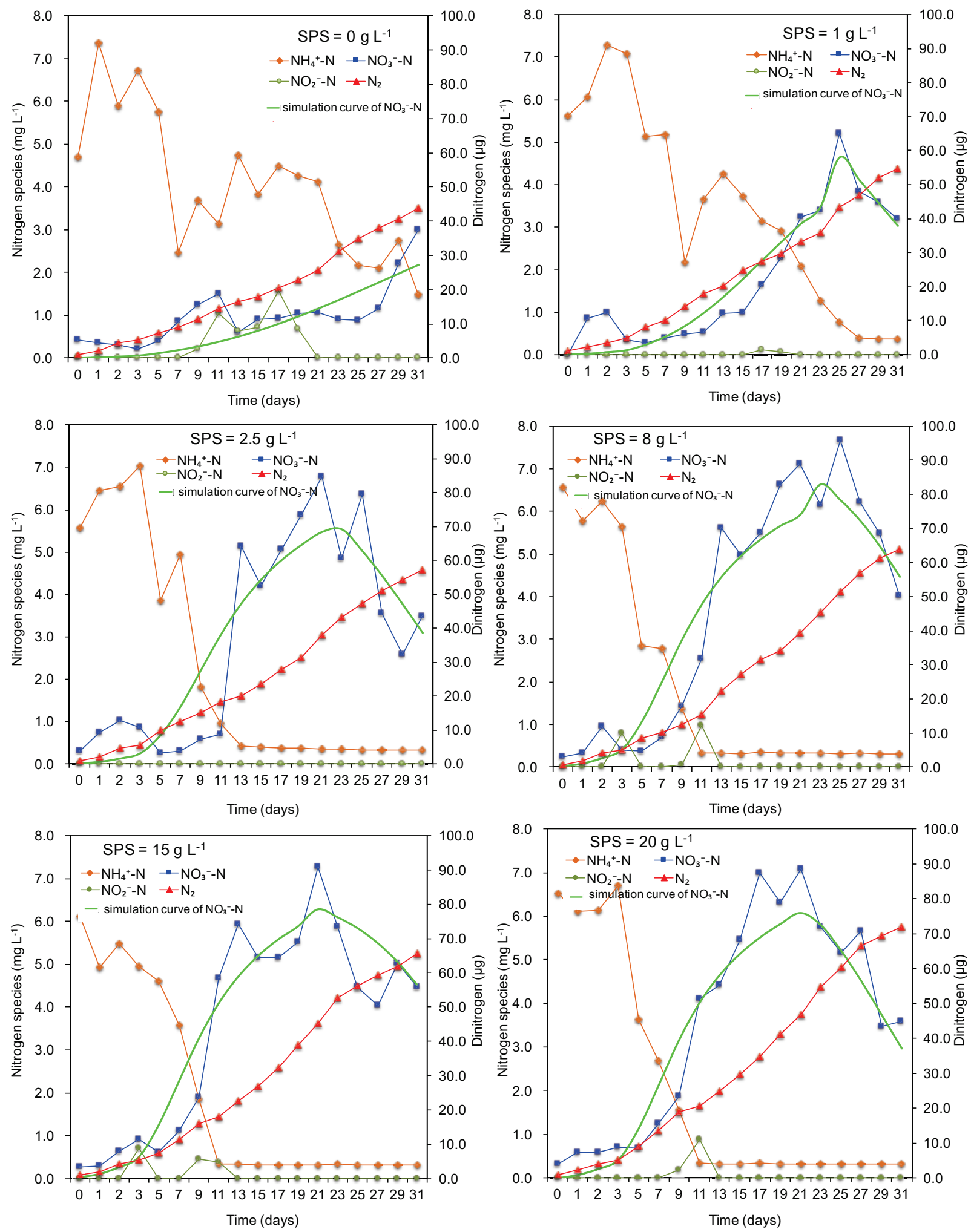

744 Figure 6 Variations of $\mathrm{NH}_{4}{ }^{+}, \mathrm{NO}_{3}{ }^{-}, \mathrm{NO}_{2}{ }^{-}$, and $\mathrm{N}_{2}$ in bed sediment-suspended sediment-water system

745 (BS-SPS-WS) containing different concentrations of suspended sediment for samples collected from

746 site HYK of the Yellow River. Data represent the average of three replicates, and the standard deviation is less than $10 \%$. 

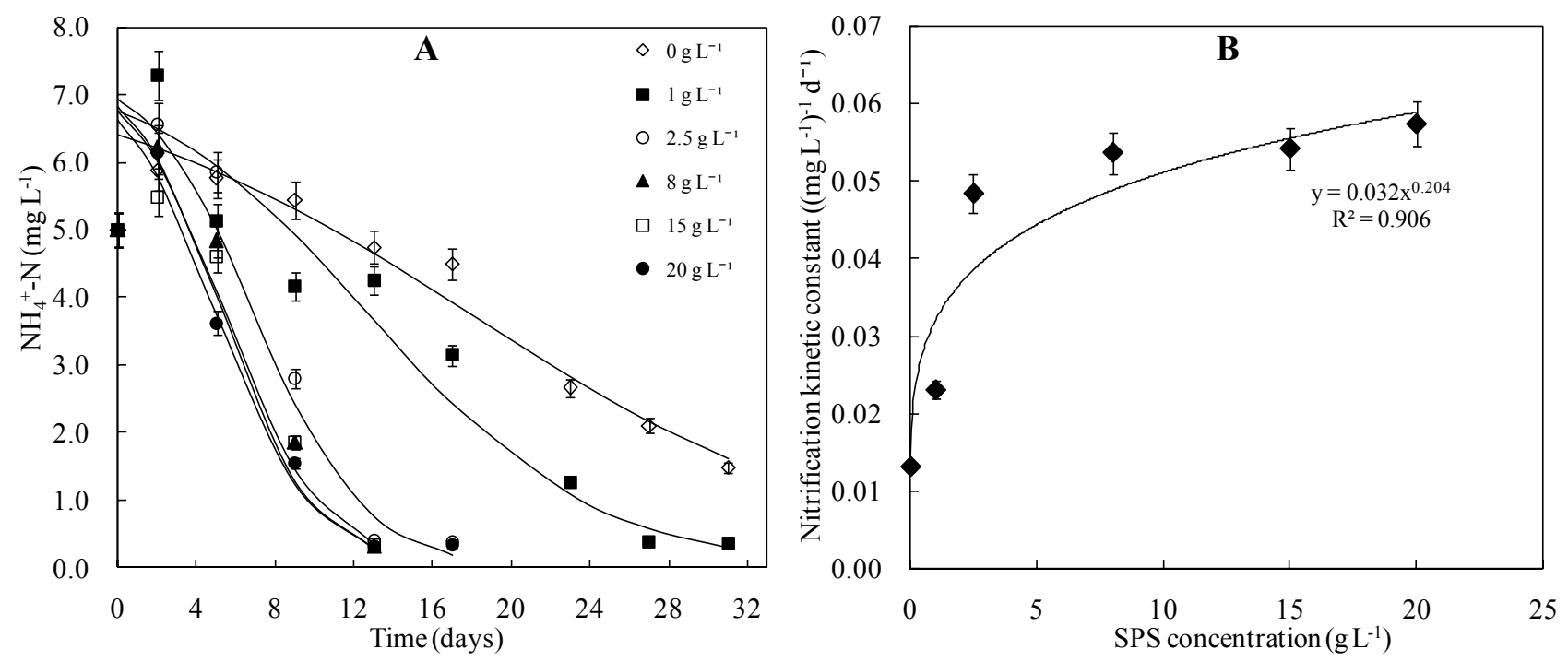

750 Figure 7 Variation of $\mathrm{NH}_{4}{ }^{+}-\mathrm{N}$ concentration with time and its fitting with the Logistic model (A), and 751 the relation of nitrification rate constants with suspended sediment concentration (B) in bed 752 sediment-suspended sediment-water system (BS-SPS-WS) for samples collected from site HYK. Data represent the average of three replicates \pm SD. 

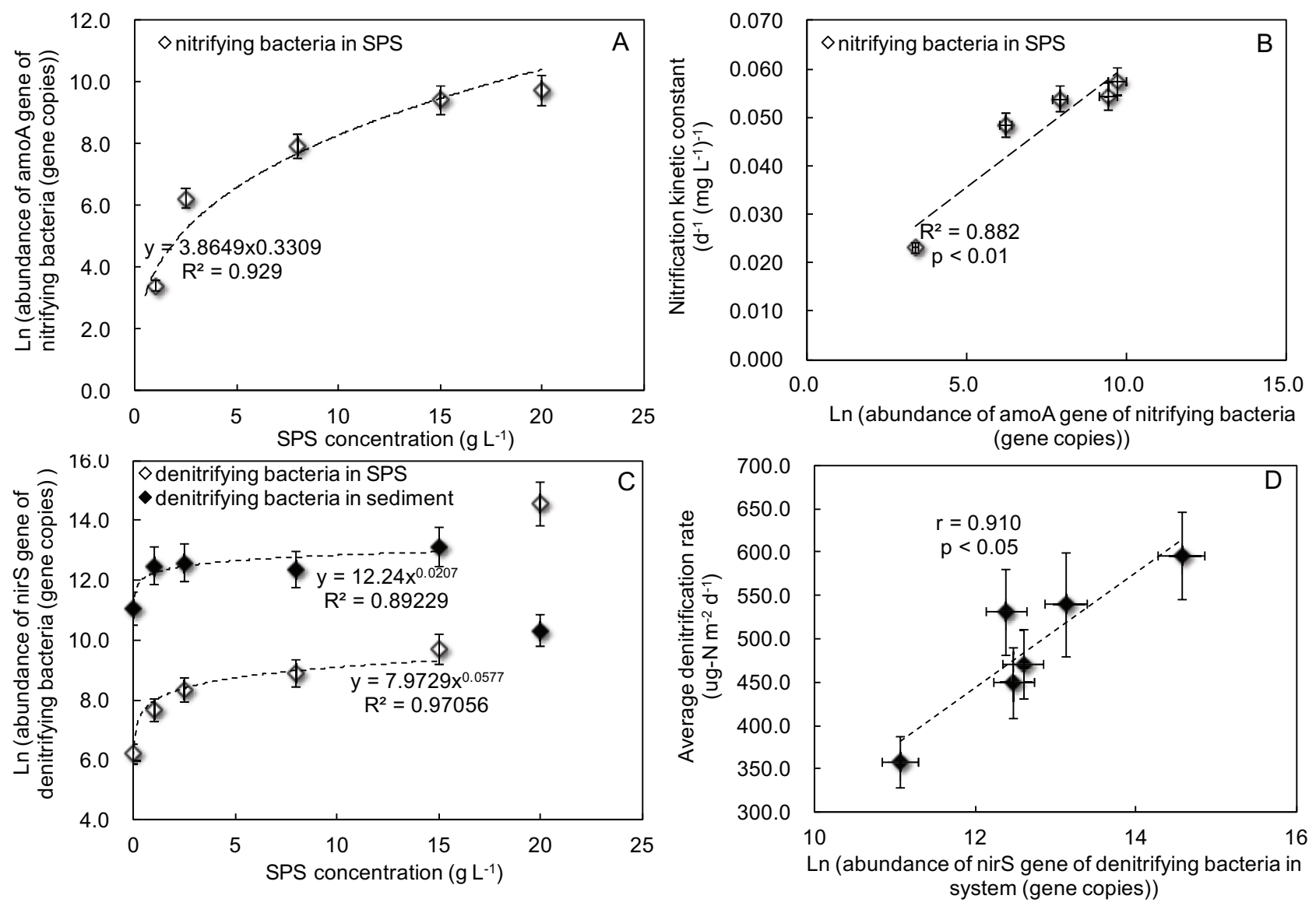

756 Figure 8 Relationship between SPS concentration and nitrifying bacteria population (A), between 757 nitrification rate constant and nitrifying bacteria population (B), between suspended sediment 758 concentration and denitrifying bacteria population (C), and between average denitrification rate and 759 denitrifying bacteria population (D) in bed sediment-suspended sediment-water system (BS-SPS-WS) 760 for samples collected from site HYK. 

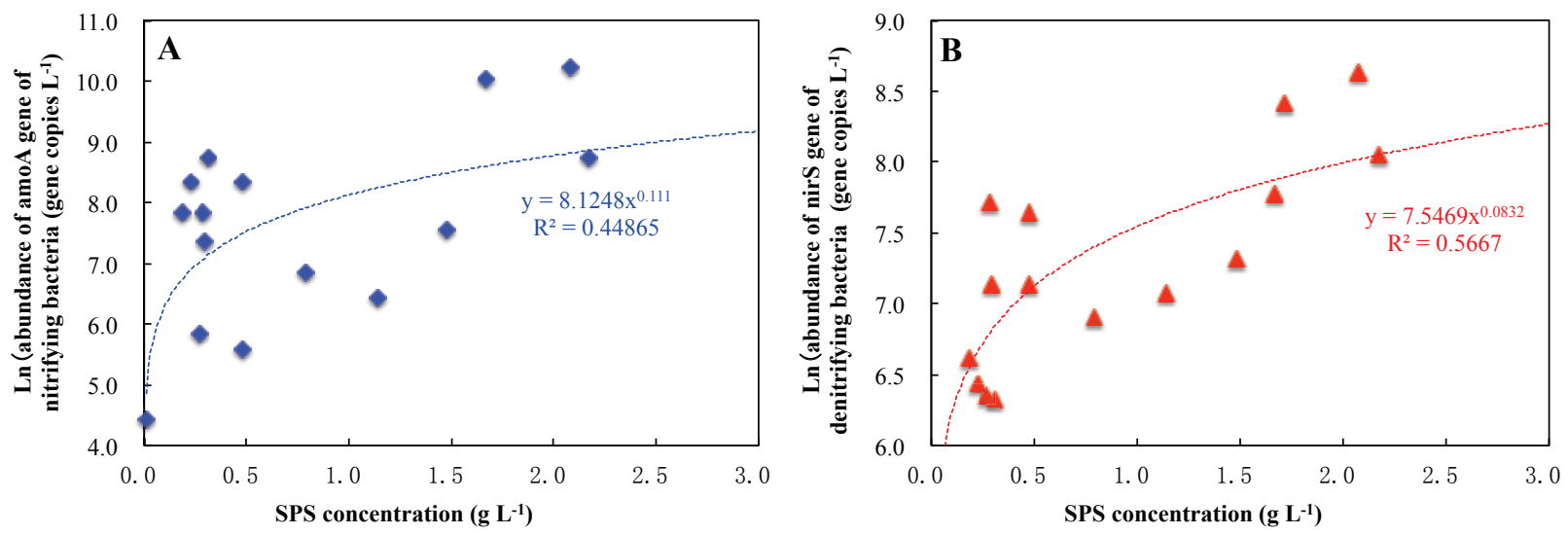

761

762 Figure 9 The in-situ nitrifying and denitrifying bacteria population in water samples

763 (containing suspended sediment) collected from the Yellow River (15 sites).

764

765

766 